Wesleyan University

From the SelectedWorks of Giulio M Gallarotti

1993

\title{
The Scramble for Gold: Monetary Regime Transformation in the 1870 s
}

Giulio M Gallarotti, Wesleyan University 


\section{Monetary regimes} in transition

S.N. Broadberry and N.F.R. Crafts, Britain in the International Economy, 1870-1939

Trevor J.O. Dick and J.E. Floyd, Canada and the Gold Standard: Canada 1871-1913

Barry Eichengreen, Elusive Stability: Essays in the History of International Finance, 1919-1939

Kenneth Mouré, Managing the franc Poincaré, 1928-1936: Economic Understanding and Political Constraint in French Monetary Policy

Larry Neal, The Rise of Financial Capitalism: International Capital Markets in the Age of Reason

Aurel Schubert, The Credit-Anstalt Crisis of 1931

David C. Wheelock, The Strategy and Consistency of Federal Reserve Monetary Policy, 1924-1933

Edited by

MICHAEL D. BORDO

Rutgers University

FORREST CAPIE

City University Business School 
Published by the Press Syndicate of the University of Cambridge The Pitt Building, Trumpington Street, Cambridge CB2 1RP

40 West 20th Street, New York, NY 10011-4211, USA

10 Stamford Road, Oakleigh, Melbourne 3166, Australia

(C) Cambridge University Press 1994

First published 1993

Printed in Great Britain at the University Press, Cambridge

A catalogue record for this book is available from the British Library

Library of Congress cataloguing in publication data

Monetary regimes in transition / edited by Michael D. Bordo, Forrest Capie.

p. $\quad \mathrm{cm}$. - (Studies in monetary and financial history)

ISBN 0521419069 (hc)

1. Money - History. 2. Gold standard - History. I. Bordo, Michael D. II. Capie, Forrest. III. Series.

HG231.M58 1993

$332.4^{\prime} 9-$ dc20 $\quad 92-43109 \quad$ CIP

ISBN 0521419069 hardback

\section{Contents}

List of figures

List of tables

List of contributors

page ix

$\mathrm{xi}$

xiii

1 Introduction

MICHAEL D. BORDO AND FORREST CAPIE

\section{Part I Commodity money standards in transition}

2 The scramble for gold: monetary regime transformation in the 1870s

GIULIO M. GALLAROTTI

3 The Latin Monetary Union and the emergence of the international gold standard

ANGELA REDISH

4 Greenback resumption and silver risk: the economics and politics of monetary regime change in the United States, 1862-1900 CHARLES W. CALOMIRIS

\section{Part II Successful and unsuccessful adherence to the} gold standard

5 Spain during the classical gold standard years, 1880-1914 PABLO MARTÍN-ACEÑA

6 Canada and the gold standard, 1871-1914: a durable monetary regime

TREVOR J.O. DICK AND JOHN E. FLOYD 
7 Australia's payments adjustment and capital flows under the international gold standard, 1870-1913

DAVID POPE

\section{Part III Wartime upheaval and postwar stabilization}

8 British and French finance during the Napoleonic Wars MICHAEL D. BORDO AND EUGENE N. WHITE

9 Interpreting a change in monetary policy regimes: a reappraisal of the first Hungarian hyperinflation and stabilization, 1921-28

PIERRE L. SIKLOS

10 Halting inflation in Italy and France after the Second World War

ALESSANDRA CASELLA AND BARRY EICHENGREEN

11 The rise and fall of credit controls: the case of Sweden, 1939-89 LARS JONUNG

\section{Part IV Perspectives on monetary regimes}

12 An assessment of monetary regimes

ANNA J. SCHWARTZ

Index

\section{Figures}

3.1 The relative price of gold to silver

page 72

4.1 Equilibrium in the currency market

4.2 Percentages of each kind of currency received from customs at New York, 1878-98

5.1 Peseta-pound sterling nominal exchange rate $1880-1914$

5.2 Relative prices, $1880-1914$

5.3 Peseta-pound sterling real exchange rate

5.4 Yields on long-term government bonds

5.6 The reserve ratio and the discount ratio

6.1 Canadian relative to foreign prices of all goods, real net capital inflows, the terms of trade, and long-term interest rates

71 Australia's product and population expansion

7.2 Components of the trade balance 204

7.3 Australia's balance of payments 204

7.4 Direct and indirect estimates of capital inflow 205

7.5 Factor migration 206

7.6 Exchange rate, 1851-1935, per pound sterling 206

7.7 Gold movements in and out of Australia 213

7.8 Major destinations of gold exports 227

7.9 Weather and capital flows 228

7A.1 Foreign reserves 229

7A.2 Change in foreign reserves 230

7A.3 Alternative measures of capital inflow 230

8.1 Great Britain, tax receipts as a percentage of commodity output

Great Britain, real deficit (surplus) 244

8.4 Great Britain, deficit as a percentage of national income 245

8.5 Yields of British and French securities, 1770-1820 247 


\title{
2 The scramble for gold: monetary regime transformation in the 1870s
}

\author{
GIULIO M. GALLAROTTI
}

\section{Introduction}

Economists and political scientists have long interested themselves in the regimes that govern economic and political systems. Both have become interested in regimes as a set of policy tools, institutions, and norms which organize political and economic relations into orderly patterns. An encompassing definition is found in Krasner (1982, p. 185): "principles, norms, rules, and decision-making procedures around which actor expectations converge in a given issue-area." More recent scholarship has shown greater emphasis on how regimes are formed and transformed. ${ }^{1}$ Disciplinary parochialism has, however, fragmented the study of regime formation and transformation. Economists have been wont to take an apolitical approach to regimes: of principal interest have been the relative efficiency of competing institutional structures, and the changes in economic relations as catalysts for institutional change. ${ }^{2}$ Political scientists have been limited in the opposite direction: approaching regime change and formation as necessarily a political phenomenon. Regimes form and are transformed through the exercise of power or changes in political power structures.

This study takes a more integrated approach in considering the formation of the classical gold standard as the resultant of a prevailing mode of transformation in domestic monetary standards during the 1870 s. $^{3}$ Beginning with the Reichstag's mandate to make the gold mark the basic unit of account and restrict the minting of territorial silver coin in Germany in 1871 , the transition from bimetallic and silver standards to a gold standard represented a compelling trend in the monetary systems of developed nations in the 1870s. Following Germany's lead, Norway, Denmark, and Sweden signed a convention in December 1872 instituting a gold standard in each nation, with silver and bronze coinage as subsidiary (i.e., token coin). By 1875 all three were members of the Scandinavian Monetary Union which was configured around central monetary status for gold (krone), with silver and bronze coin relegated to subsidiary roles. In that 
year Holland continued the provisional suspension (which had begun in 1873) of coining silver and introduced the 10-gulden gold coin as the central coin. This ad hoc gold standard was formally institutionalized in 1877 when the coinage of silver was definitively suspended.

The United States, having arguably perpetrated a transition from bimetallism to gold in 1853 , in the 1870 s mirrored the European trend of legislation against the central monetary status of silver. ${ }^{4}$ The de facto gold standard already existing was consolidated. The Law of 1873 demonetized the 412.5-grain silver dollar, thus making the gold dollar the central legal unit of account. The Act of 1878 reinstituted the silver dollar but under a policy of limited government purchase and coinage. In the following year Austria-Hungary closed its mints to silver, although its formal adoption of a gold standard was still more than a decade away.

Belgium, reacting to an enormous influx of silver in 1873 , limited the coinage of 5-franc silver pieces at the Brussels mint. A similar influx into France caused the coinage of 5-franc pieces at the Paris mint to be limited in the same year. In the following year, the Latin Monetary Union (whose principal members were France, Switzerland, Italy, and Belgium) instituted 5-franc coinage limits for all its members. The limits were renewed and adjusted in 1875 and 1876. In 1876 France and Belgium suspended the coinage of 5-franc pieces. In 1878 the coinage of the 5-franc piece was suspended over the entire Latin Union membership. ${ }^{5}$ With this cessation of the coining of the Union's central coin, noted Helfferich, "the fate of silver as a money metal was sealed, insofar as [economically developed] European countries were concerned," $(1927$, p. 181$){ }^{6}$ What began as a decade which saw only two nations of note (Great Britain and Portugal) legally on a gold standard ended with the developed world firmly entrenched in the practice of gold monometallism. This "scramble for gold," as White called it (1893, p. 27), had in one short decade abrogated the practices of centuries. ${ }^{7}$

The formation of an international gold standard was a natural outcome of redundance in domestic monetary standards. As more nations adopted a gold standard domestically, a greater international gold bloc crystallized. In this case, the creation of an international regime was an additive process. As Ludwig Bamberger argued, "a world monetary union would be superfluous if all countries based their currencies on gold." 8 Things equal to the same thing are equal to each other. And gold monometallist orthodoxy was fairly uniform over those nations practicing such a standard. Each nation could be expected to maintain a stable value in the central monetary unit by defending convertibility. Each could be expected to maintain a high level of private discretion over the management and movement of gold stocks (i.e., individuals were free to hold gold in various forms as well as to import and export it freely). Thus a stable set of exchange rates and expectations regarding monetary relations emerged from a convergence of monetary practices at the domestic level.

It is difficult to impute any international consciousness in the national policies that marginalized silver in monetary standards of this period. The creation of an international gold standard showed neither intention nor the exercise of international power. Monetary cooperation in this period, primarily embodied in the International Monetary Conferences of 1867 and 1878, was unsuccessful at creating any kind of formal international monetary agreement. The latter conference, in fact, was initiated by the US to discuss the possibility of an international bimetallist union. As for the four core (i.e., dominant) monetary powers of the period - the United States, France, Great Britain, and Germany - none exercised any political or economic power (aside from initiating international discussion) in bringing about an international regime, either individually or collectively. Great Britain, the so-called monetary hegemon of the period, not only avoided any unilateral initiatives at creating international institutions, but was exceedingly uncooperative at supporting any initiatives in the Conferences of 1867 and $1878.9^{9}$ Thus, the creation of this regime cuts against the standard political-science vision. It can best be described as a decentralized or diffuse process, where the formative elements and rationalization of an international monetary system were dispersed among a number of individual national monetary standards, rather than deriving from international conference rooms where nations conceived of and collectively coordinated their monetary practices. ${ }^{10}$

For the political scientist, understanding the formation of the international gold standard represents a study in the formation of diffuse regimes. This pertains particularly to the interests of international-relations specialists and students of comparative monetary history. For the former, it illuminates a much neglected area in the study of regimes. For the latter, it illuminates processes in which the confluence of shared external and internal pressures filter through domestic political and economic structures to create uniformities in national policy styles. This bears directly upon how comparative monetary systems converge upon common institutions. For the economic historian, who has been more concerned with how the gold standard worked than with how it formed, it proposes and answers an alternative set of questions regarding how monetary systems crystallize. ${ }^{11}$

The scramble for gold in the 1870 s can principally be understood as a resultant of two types of forces: structural and proximate. The former refer to long-term and developmental forces in the nineteenth century that compelled nations away from silver-based standards toward gold. Specifically, these were (1) a growing ideological attraction to gold and aversion to silver, (2) industrialization and economic development, and (3) changes in 
political power structures. Proximate forces represent critical developments in the 1860s and 1870 s that served as the immediate catalysts for legal changes in monetary standards. Structural forces incrementally compelled the shift to gold, but it was these critical developments that accounted for the timing of the transformation.

The chapter is organized as follows. The first section discusses the structural foundations of the movement toward gold. The proximate foundations of the movement are then considered, and a final section concludes the article with a discussion of some central implications for monetary regime theory.

\section{The structural foundations of the classical gold standard}

As the nineteenth century progressed, three sets of structural forces increasingly compelled national monetary authorities toward gold and away from silver as central monetary metals. First, nations came to see monetary standards as economic and political status symbols: gold monometallism came to confer high status, while silver and bimetallism came to confer low status. Second, industrialization, economic development, and the growth of international trade encouraged the greater use of the more convenient metal (gold). ${ }^{12}$ Finally, the spectrum of class politics changed significantly in the nineteenth century. The rise of liberalism was a manifestation of the political rise of an urban-industrial class and a challenge to the traditional dominance of an agricultural class. With the shift in the political balance of power came a concomitant shift in monetary preferences from a standard oriented around a bulky and inflationary metal to one oriented around a light and non-inflationary metal.

\section{The ideology of gold}

According to Joseph Schumpeter $(1954$, p. 770$)$ it is difficult to explain prevalent cases in the transition from paper standards to gold standards in the last two decades of the nineteenth century independently of a "noneconomic" factor: the quest for monetary "prestige." Italy, AustriaHungary, and Russia shifted from a non-metallist regime where paper was depreciated in terms of silver to one in which monetary units were raised to an arbitrary gold parity, all of this occurring in decades exhibiting low or negative inflation. Moreover, some of the dominant economic interests in those nations were opposed to fixing exchange rates. This is explicable, Schumpeter argued, when we realize that gold monometallism as a standard had become a "symbol of sound practice and badge of honor and decency," and that national monetary authorities were compelled by the "admired example of England." In other words, gold monometallism had become an ideological focal point. As a standard, it was imputed a value which was independent of purely economic advantages (e.g., non-inflationary standard, low transaction costs in exchange). What Schumpeter attributed to monetary authorities of the 1880 s and 1890 s, can no less be attributed to authorities of earlier decades.

The Marquis de Moustier, presiding at the International Monetary Conference of 1867, stated that "sentiments" independent of economy held sway over monetary institutions, and that such sentiments were largely based on ideological attachments to certain practices (e.g., fondness for certain coins, fear of innovation). Gold monometallism, he suggested, generated such sentiments, and it was desirable for the Conference to assure that these sentiments were fulfilled. ${ }^{13}$ The sentiments in this period generated an ideological attraction for gold and an ideological aversion to silver, so it is not surprising that the Conference ended with a unanimous call for a monetary union founded on gold. ${ }^{14}$

The ideological attachment to gold emanated primarily from a propensity on the part of monetary authorities to make associations between national monetary practices and greater achievements in the global economic and political order. Authorities became sensitized to a prevailing association: there was a strong relationship between the importance which gold played in national monetary systems, and the levels of economic development and political importance of those nations. By the later 1860s it became clear that gold was perceived as "the natural standard of the stronger and richer nations, and silver of the weaker and poorer nations." 15 Ernest Seyd of the United States, in his letter to the US Monetary Commission (US Congress, Senate, 1876, vol. II, p. 115), cited the prevalence of the belief that "civilized nations" should use gold and "uncivilized nations" silver. ${ }^{16}$ The Swiss monetary diplomat Charles Feer-Herzog went so far as to call silver the "inferior metal." 17

The unanimous support for gold monometallism at the International Conference of 1867 was taken by many as the most overt manifestation of a growing monetary division of the world. Feer-Herzog's own assessment of this development was widely accepted. It was acknowledged that the Conference split the world into two monetary spheres: a gold sphere characterized by nations that were "civilized, rich, and active" and a silver sphere of "less advanced" nations. ${ }^{18}$ The perceived relation between international political/economic status and monetary practices provided potent ammunition for the supporters of gold both in national and international monetary debates. Supporters of gold at meetings of the French Monetary Commission of 1868 , for example, were not reserved in their use of this association in trying to discredit silver and bimetallism as future 
standards for France. ${ }^{19}$ At the International Monetary Conference of 1878 the Dutch representative Mees expressed his pessimism about the possibility of a bimetallist alliance forming among the US and European states, but added that the US might look for monetary "allies" in the lessdeveloped world (Central and South America, Asia, Dutch and English Indies). Russell (1898, p. 224) noted that Mees' comment may have contained some quiet ridicule of the United States' attempts to resuscitate silver by intimating that the US could be monetarily classified in a group of underdeveloped nations. One US delegate (Horton), in fact, requested a clarification of what Mees intended when he cited these prospective US monetary alliances. ${ }^{20}$

The status of gold derived disproportionately from the British example. That Great Britain was not only a monetary role model but also an economic-policy role model in the nineteenth century is generally acknowledged in the historical literature on the period. ${ }^{21}$ Michel Chevalier (1859) underscored how readily French and other European authorities imitated British financial innovations. ${ }^{22}$ On all dimensions of monetary policy, nations would "turn to England for financial wisdom." ${ }^{23}$ The compelling nature of the British example is attributable to what Jervis (1976) called "overlearning from history": i.e., hastily attributing a cause and effect relationship to a simple existing association.

In explaining the attraction of gold after 1850, Edward Atkinson and William Sumner's testimonies to the US Monetary Commission (1876, vol. II, pp. 274, 275, 356) representatively conveyed the prevailing lesson.

The tendency of opinion in Europe had been for 20 years in favor of the monometallic system. From the example of England it was seen that the English by the mono-metallic system of a gold standard enjoyed great advantages, and the Continental nations, especially Prussia, seeing this, decided to go into the monometallic system ...

the prosperity of England is due largely to its monetary standard . . . [T] hose [nations] who adopted gold as their standard of value have . . . been most permanently prosperous.

Certainly there were many who were skeptical about the nature of the causal link. Disraeli, in fact, saw causation in reverse. The gold standard, he averred, "was not the cause but the consequence of our commercial prosperity." 24 For the US monetary diplomat Dana Horton the purported causal link became a "doctrinaire propaganda" used by the advocates of gold to drive out silver. ${ }^{25}$ Horton added that irrespective of its propagandistic nature, the lesson drove nations to transform their monetary standards. ${ }^{26}$ This lesson was especially compelling for Germany.

For Germany, this was certainly one of the principal factors underlying its strong predilection toward gold after 1860 . The period marked, in fact, a high point in what Stolper (1940, p. 33) called Germany's "Western orientation." It was most visible in liberal-elite circles championed by Ludwig Bamberger and Delbrück, and supported strongly by Bismarck who had venerated Western styles in policy from his early years. Bamberger himself, the single most important influence on German monetary unification in the early 1870 s, saw the Western trend as being one characterized by the growing displacement of silver by gold. ${ }^{27}$ Bamberger, Camphausen, Delbrück and other leading Liberals were "dazzled by the universal sway of gold" in developed countries. ${ }^{28}$ These men saw gold (in that it was a fundamental part of the Liberal economic-policy agenda) as a means of what one publicist of the period referred to as putting Germans "in the same position as the citizens of the great industrial states."29

Within the Western bias, the British precedent was especially compelling, and it was as strong in trade as monetary policy, German trade liberalization in the 1840 s being encouraged by the British example. ${ }^{30}$ Bismarck's banker and financial advisor Bleichröder noted the prevalence of a desire in certain elite circles "to tailor our [monetary policies] to the British pattern." 31 The gold mark became a symbol of the German challenge to the politico-economic hegemony of the British, as "the [gold] mark could take its place besides the pound as the mainstay of stability in the West."32 The importance of monetary status was made all the more evident by the questionable economic rationality of a sudden transformation of six Germanic monetary systems traditionally founded on silver and paper circulation (only Bremen was on a gold standard). US Secretary of the Treasury McCulloch (1879, p. 16), in fact, argued that a rapid transition to gold monometallism was a mistake. Germany, he added, paid a great price for "[placing] herself along side of Great Britain." She risked severe deflation and could not match Britain's capacity to keep gold and thus maintain convertibility. ${ }^{33}$

Monetary ideology also had a place in US monetary history in the eighteenth and nineteenth centuries. White (1893, p. 6) argued that Hamilton's advocacy of bimetallism in the late eighteenth century was founded on a veneration of the policies of prominent European nations. Some of the most powerful political forces behind the Gold Bill of 1834 (which changed the legal ratio from $15: 1$ to $16: 1$, thus overvaluing gold at the mint and causing the displacement of silver) advocated increasing gold circulation based on tradition ("[our] fathers once possessed it") and prevailing practices elsewhere ("the subjects of European kings now possess [it]"). ${ }^{34}$ The Act of 1853 was preceded by Congressional diatribes in the early 1850 s against bimetallism, citing such practices as being antithetical to what the leading political economists of the day approved. ${ }^{35}$ Representative Dun- 
ham, who on behalf of the Ways and Means Committee introduced the bill that would become the Act of 1853, associated various economic advantages with a gold standard based on the "experience of every nation which has attempted it." 36

It is not clear, however, that gold held an ideological advantage over silver throughout the nineteenth century in the US. The US was consistently metallist, but the balance of ideology among silver and gold tended in general not to be skewed. ${ }^{37}$ Friedman and Schwartz (1963, p. 109) identify regional attachments to metals, the East being sympathetic to gold, and the West and South being sympathetic to silver. ${ }^{38}$ One can add to this division urban versus rural attachments. And although US monetary legislation in the 1870 s appeared not to have the same ideological force behind it that legislation in Germany did, evidence suggests that both supporters of gold and silver came to the realization that gold was becoming the universal standard, and that this represented a compelling factor in Congressional decisions over appropriate policies. ${ }^{39}$

French metallist ideology seems to have been amenable to bimetallism throughout the nineteenth century. Much of the ideological attachment was founded on tradition, i.e., venerating the monetary practices of their revolutionary ancestors as manifest in the legislation of 1803 and 1811.40 Napoleon III's Saint-Simonian policy leanings and personal veneration for British economic policy styles appeared to create the seeds of an ideological attachment to gold in the Second Empire. ${ }^{41}$ But his dependence on the Bank of France for financing his foreign campaigns sensitized him to the Bank's (as well as the Finance Ministry's and haute finance's) advocacy of bimetallism, an advocacy sustained by a history of lucrative arbitrage in the two metals. ${ }^{42}$

Like France, the metallist ideologies of Latin Union members Italy, Switzerland, and Belgium seemed somewhat ambiguous, and the ideological factors underlying their policies in the 1870 s are difficult to tease apart from other structural and proximate factors. Italy's adoption of the French monetary system in 1862 was stimulated by gratitude to Napoleon III for facilitating unification, as well as Victor Emmanuel's loyalty to the monetary practices of his native Sardinia. The Belgian Chambers in 1847 sought to introduce a gold circulation based on a "patriotic desire."43 Holland, if anything, was ideologically silverite and bimetallist, with a strong royal and popular attachment to silver, ${ }^{44}$ although, as with Latin Union countries, the strength and independence of ideology in the Dutch case are problematic. Evidence on the Scandinavian countries did not show any overwhelming ideological stimuli in their conversion to gold.

Of the nations that experienced policy transformations in the $1870 \mathrm{~s}$, the structural effects of ideology seem to have been strongest in Germany, and somewhat less compelling in other nations.

\section{Industrialization and economic development}

Laughlin (1886), White (1893), and Helfferich (1927) all accounted for the scramble of the 1870 s as part of a general monetary evolution that continually causes inconvenient monies to be replaced by more convenient monies. The impetus for a more convenient metal was the result of the industrial revolution. The size and amount of economic transactions grew with economic development, and growing economic activity spilled out internationally as the level of foreign trade increased. This naturally increased the burden of using silver, the metal with much higher transaction costs in exchange.

At the time, O.D. Ashley noted that

[Gold] is less bulky and easier to transport, more convenient to carry upon the person, and more easily guarded against theft or destruction. Ten dollars in silver would be an uncomfortable weight in the pocket, while in gold it would make no perceptible difference... If there were no other reasons than these, they seem strong enough to give gold the preference as the principal measure of value. ${ }^{45}$

Chevalier $(1859$, pp. 39, 40, 94; 95) argued that just as Rome stopped using bronze when silver became sufficiently abundant, gold came to displace silver when it became available in sufficient amounts in the $1850 \mathrm{~s}$. For Parieu the events of the latter nineteenth century fit perfectly into a pattern that saw "mineralogical, industrial, and commercial circumstances" lead to metals of superior "portability and density" replacing those of inferior portability and density. It is perfectly natural, he argued, that "silver first took the place of iron and copper, and . . . silver is now displaced by gold." 46 According to Edward Atkinson of the US, the rise of gold in the 1870 s was a process of "natural selection." 47 Helfferich (1927, p. $118)$ pointed out that the increased use of gold after 1650 was contemporaneous with the spurt in international trade in the seventeenth century. ${ }^{48}$ He further identified the British commitment to gold monometallism in the late eighteenth and early nineteenth centuries as deriving from a concern over the convenience of exchange. 49 "Great civilized communities," argued Chevalier (1859, p. 95), "modify the machinery of their exchanges, in proportion as commerce extends its operations and enlarges its spheres."

Laughlin (1886, pp. 168-170) identified a "one-way" trend in the evolution of monetary policy in the nineteenth century. Nations, he said, allowed gold to displace silver in circulation in the 1850 s and 1860 s, but would not 
tolerate the opposite trend in the $1870 \mathrm{~s}^{50}$ Nations were more troubled by a lack of gold than by a lack of silver. Russell $(1898$, p. 202) referred to this nineteenth century policy bias as "the natural tendency with advancing civilization to give to gold a quality as a measure of values which it denies to silver." 51

This suggests that there was a systematic instability in bimetallism after 1850 that would have made it difficult to sustain cyclical shortages of gold emanating from the workings of Gresham's Law. Such cyclical shortages affected both metals in bimetallist regimes throughout the nineteenth century, which essentially rendered the practice of bimetallism an alternating monometallist standard. ${ }^{52}$ Under any hypothetical bimetallist regime, if the market bimetallic ratio is distributed randomly around the prevailing legal (i.e., mint) ratio over time, and divergences between the two ratios make arbitrage in metals profitable (i.e., are greater than the transaction costs of arbitrage), then Gresham's Law will produce alternating abundances in one metal (the bad money, or that money whose mint value exceeds its intrinsic value) and shortages in the other (the good money, or that money which is undervalued at the mint). It is clear that nations' oneway orientation toward media of exchange in this period would have tolerated periods of de facto gold standards more than periods of de facto silver standards. ${ }^{53}$ In this respect, preferences seemed to "tip" toward gold as a central metallic medium of exchange. ${ }^{54}$ Hence, it appears that bimetallism after the 1850s might not have been as stable as Friedman (1990a, $1990 \mathrm{~b}$ ) has contended. Nations would have instituted restraints against recurrent shortages of gold, and in the $1870 \mathrm{~s}$, this took the form of demonetizing silver. ${ }^{55}$

The transformation of monetary standards was not independent of the greater evolution of financial institutions in the nineteenth century. Rapid industrialization and economic development after 1850 shaped financial institutions in the developed world according to new imperatives: Nowhere was this more evident than in Germany and France where the development of banking systems capable of handling long-term industrial lending was a response to the needs of the new industrial economies on the Continent. ${ }^{56}$ Bouvier's term for the transformation of French banking in the nineteenth century ("cosmopolitan") aptly fits the transformation of monetary standards. Gold was the more cosmopolitan standard and silver the more rustic since gold was better adapted to an urban-industrial economy and silver to an agricultural economy (where transactions are fewer and smaller). As an issue of the Economist (1866, p. 1252) of the period pointed out, "Gold money is becoming the money of commerce . . . The large obligations of modern times are best settled in a costly metal. Gold is . . . the wholesale money of mercantile nations." H.R. Linderman testified to the
US Monetary Commission (1876, vol. II, p. 199) that irrespective of what standard nations adopted in the 1870 s, people would not transact in silver. If they could not use gold, he argued, they would use paper. ${ }^{57}$ Transactions in coin after 1850 were still sufficiently abundant to make convenience in domestic exchange an important issue. As late as 1856, 80 percent of French payments were effected in metal (50 percent gold and 30 percent silver), while only 20 percent were effected in bank notes. By 1891 France still had 160 million pounds' worth of coin in circulation. In Italy in 1865 only onetenth of the money in circulation represented bank notes. ${ }^{58}$ Even in Great Britain the need for gold in transactions was pronounced up until the First World War. ${ }^{59}$

If we differentiate between the early and/or rapid industrializers of the nineteenth century and the late and/or slow industrializers, we see a division of monetary actions in the 1860 s and 1870 s that is roughly consistent with the expected structural preferences. The early and/or rapid industrializers, Great Britain, Germany, Sweden, Denmark, Switzerland, and Belgium, can be said, as a group, to have fought harder to attain and retain gold standards in the 1860s and 1870s. The late and/or slow developers, France, the US, Italy, and Holland, fought less hard. ${ }^{60}$ Holland was the only nation at the International Monetary Conference of 1867 to oppose the overwhelming call for the international adoption of gold monometallism. The US and Italy fought the hardest at the International Conference of 1878 to bring nations back to bimetallism. France, of course, stayed de jure with a bimetallist standard through the first half of the 1870 s, as other nations turned to gold. ${ }^{61}$

In Germany, the call for gold on grounds of convenience was seen as early as the 1830 s from the economist J.G. Hoffman, in the South German States Union (1837), and in the Dresden Agreement (1838). This was part of an ongoing call for a rationalization of German monetary and economic systems to bring Germany more into line with economic modernization on the Continent. The call was most visible in resolutions issued by the Congress of German Economists which met regularly throughout the nineteenth century. ${ }^{62}$ The supply of gold in Germany before 1850, however, was far too small to institute a gold standard. The father of German monetary unification Ludwig Bamberger himself believed in the inevitability of the movement toward more convenient mediums of exchange in Germany. Under any dual-standard system, he reasoned, the more convenient standard will displace the less convenient. ${ }^{63}$ Both White (1893, pp. 14, 15) and Helfferich (1927, p. 149) saw convenience as a principal factor behind the course of German monetary unification in the $1870 \mathrm{~s}$.

In the US, monetary experts questioned the rationality of maintaining a standard with silver coins in large denominations. John Sherman (1895, 
p. 696) argued that even if the American silver dollar were remonetized in the 1870s, Americans would shun it due to its inconvenience; they would opt for paper instead. ${ }^{64}$ By the 1870 s the US was indeed showing the normal developed-nation structure of exchange: larger transactions moving away from silver. ${ }^{65}$

In the Latin Union states of Switzerland, France, Belgium, and Italy, the infusion of gold coin during the 1850 s and 1860 s was received quite favorably, especially among commercial groups. ${ }^{66}$ In France, the Finance Ministry in 1858 underscored how tolerant the French were of the situation of the 1850s when gold flowed in and silver departed. ${ }^{67}$ White (1893, p. 19) noted how the French after 1850 were happy to rid themselves of the inconvenience of carrying around heavy sacks of 5-franc silver pieces in cabs and handcarts. Chevalier (1859) argued that the French acceptance of gold in the 1850s was functionally similar to the British situation earlier in the century, diverting to a more convenient medium of exchange once it became abundant. ${ }^{68}$ The French economist Levasseur saw the 1850 s and 1860 s in France as a time of monetary evolution. He added that practices should conform to evolutionary realities, and that the more fit metal (gold) should be made the central money. ${ }^{69}$

In Belgium in the 1840s, one of the principal factors encouraging the Belgian Chambers to introduce a gold coin in 1847 was a concern for the preferences of business for a more convenient medium of exchange. ${ }^{70}$ In Switzerland the proliferation of French gold coins in the early 1850s was greatly welcomed by Swiss business interests who found the new coins much less cumbersome. Swiss chambers of commerce, and banking and mercantile associations put constant pressure on the Bundesrath in the 1850 s and 1860 s to insure a convenient standard. The financial community actually based its transactions on French gold through the Bankvaluta system which dictated, among other things, that bills were payable in French gold. ${ }^{71}$

Among Scandinavian nations it became a major imperative to replace a burdensome silver standard with more convenient money. ${ }^{72}$ Holland was less resolute in making the transition to gold, and evidence regarding the compelling convenience of gold appears less for Holland than for other Western European nations.

The growth of an international economy in the nineteenth century compounded the effects of domestic economic development on the choice of a monetary standard. For Unger (1964, p. 331), "the strong, world-wide current for an international gold standard [was a response to the] rational needs of a developing international economy." The enormous growth of trade in the middle decades of the century naturally conferred a greater attractiveness onto the superior trade-clearing metal. ${ }^{73}$ Gold's importance in foreign trade had historically preceded its importance as a domestic medium of exchange. It was not uncommon for nations on standards other than gold to clear their trade payments in gold. In Sweden, for example, the silver rix thaler was the central monetary coin, but trade was cleared in gold ducats. A dual standard was also practiced in Argentina where gold became the medium for international payments, while paper became the domestic medium of exchange. ${ }^{74}$

One major concern behind the attempt at an international monetary union at the Conference of 1867 was with reducing the transaction costs of foreign trade through the institution of a common gold standard. Laughlin (1886, p. 152) underscored the pressure put on French monetary authorities to use gold as a result of the growth of trade after 1848. In Belgium, where the trade sector was large relative to the economy, the pressure for gold was especially acute.

The growth in trade also served to compel nations toward Great Britain's standard because most of the world's trade was cleared in London. Moreover, with the growth and internationalization of finance, the standard used by Great Britain became more compelling as financial institutions were drawn into an international market place for financial services and investments dominated by the London market.

Here again, gold was part of a greater movement at the time: that for international standardization. Russell $(1898$, pp. 82, 83) talked of the consensus at the International Monetary Conference of 1867 for gold as being reflective of a "spirit of the times." Part of this Zeitgeist was a movement toward reducing the transaction costs of international interdependence by standardizing the means of transportation, communication, and exchange. ${ }^{75}$ It was visible as early as the 1850 s in the agitation for the standardization of weights and measures. ${ }^{76}$ The sentiment extended in the 1860 s to calls and initiatives for international monetary unification, of which the International Monetary Conference of 1867 was the highpoint. ${ }^{77}$ Ludwig Bamberger and John Sherman argued that with the growth of commerce, nations would be increasingly compelled toward conformity in their monetary systems. ${ }^{78}$ The complex calculations required in determining the values of foreign currencies without standardization, and the foreign exchange charges incurred by merchants became more burdensome as trade grew.

For reasons both of growing domestic and international exchange, therefore, silver was increasingly perceived to be obsolete as a central monetary metal.

\section{The politics of gold}

The victory of gold over silver in the 1870 s was as much a political as it was a practical and ideological victory. As with most economic institutions, 
monetary practices exhibited a consistency with ongoing political developments in the world. The growing attraction of gold over silver partly reflected changing political power structures across the nineteenth century. A rising urban-capitalist class (professionals, business, banking) was displacing an agricultural class (farmers and landowners) in the politica hierarchy, and the monetary victory of gold over silver and bimetallism was in many ways coterminous with the political victory of the bourgeoisie. ${ }^{79} \mathrm{It}$ is not surprising that Great Britain was the first to go to gold, given that this political struggle was first resolved there.

Clough and Cole (1946, p. 358) argue that the liberalism of the nineteenth century was the "class philosophy" of a rising urban-industrial class. Monetary philosophies can also be differentiated according to particular class preferences in this period. The virtues of gold were best adapted to urban-industrial interests, while silver and bimetallism were better adapted to agricultural interests. Gold was naturally the preferred metal for business interests given that its convenience most efficiently expedited transactions. ${ }^{80}$ Creditor (banking) classes would naturally favor the metal that was perceived to be historically most stable, and the nineteenth century witnessed a widespread perception that gold was that metal. ${ }^{81}$ Starting in the 1860 s the value of silver began a secular and precipitous decline, thus definitively casting pro-inflation (agricultural) interests on the side of silver, and stable-money (urban-industrial) interests on the side of gold. But even before the $1870 \mathrm{~s}$, many creditors had been collecting debts in gold. ${ }^{82}$ Moreover, stable-money interests sided with monometallism, while proinflation interests sided with bimetallism. First, there was the conviction that a multiple metallic standard would encourage a larger money supply. Second, under bimetallism debtors had the benefit of accepting loans in an appreciating metal and liquidating in a depreciating metal. ${ }^{83}$ To some extent, this narrowed the monetary menu to a choice between gold and silver monometallism in a period when the silver standard was the least acceptable (ideologically and economically) metallist option. ${ }^{84}$ By the $1880 \mathrm{~s}$, the creation of an international bimetallist league to abate the decline of silver had become politically impossible. ${ }^{85}$

Germany's political transition in the nineteenth century was less complete than that of other Continental nations, but with respect to the structure of influence over monetary issues, it fitted well into the Continental trend. The rise of the urban industrial classes on the Continent manifested itself in the rise of liberal parties. In Germany the party of note was the National Liberal Party which, according to Stern (1977, p. 177), came to represent the interests and ideals of the German middle class (academics, industrialists, urban professionals, bankers, merchants). It crystallized from the fracture of liberal politics in the 1860 s and emerged as the principal challenger to the German Conservatives, a party strongly grounded in agricultural interests (peasants and landowners). In the $1870 \mathrm{~s}$ liberals became the dominant party in the Reichstag (they had as many as 40 percent of the seats in 1874).

The political struggle between classes, in Germany and on the Continent as a whole, was coterminous with the struggle between autocratic government and parliamentary government. In Germany it was specifically between the Crown (the conservative bases of power were the army, bureaucracy, and the Crown) and the Reichstag. Bismarck, whose own leanings dictated a conservative government in Germany, was intent on resolving this dispute in a way that would bring about unification founded on a clear conservative hierarchy which was supported by an urbanindustrial class; he felt no government was sustainable without the backing of the two economic pillars of the German state (agriculture and industry). ${ }^{86} \mathrm{He}$ therefore orchestrated a quid pro quo which configured domestic economic policy according to the preferences of liberals in exchange for liberal support of a conservative government. Led by Bamberger, the liberals were able to impose their monetary agenda onto reluctant conservatives. ${ }^{87}$

In the Latin Union and Northern European nations, there was much more continuity between real political influence and economic policy. The Second Empire (1852-71) saw France make major strides toward a government consistent with liberal principals. ${ }^{88}$ Politics became inextricably tied to the preferences of the rising economic classes. Napoleon III's own power elite (appointed ministers) came disproportionately from the grand bourgeoisie (merchants, financiers, and industrialists). The legislature (Deputies) came to be dominated by former civil servants and the grand bourgeoisie, each more numerous than landowners. ${ }^{89}$ Napoleon's political agenda was not functionally dissimilar to Bismarck's. Both men courted a broadbased coalition of political movements under a fundamentally conservative banner, Napoleon seeking a union of the masses, aristocracy, and bourgeoisie under a Bonapartist masthead. Both courted the middle classes through economic reforms in the full realization that no French or German government could be viable in the absence of bourgeoisie support.

Switzerland and Belgium, after many years of liberal agitation, saw the entrenchment of liberal governments by the 1870 s. Belgium's liberal constitution, founded after independence from Holland in 1830, set a European precedent. Liberals, representing the large-town bourgeoisie, dominated Belgian politics from 1847 to 1870 , and the Liberal party under M. FrereOrban took formal control of the government in $1878 .{ }^{90}$ Switzerland, even before federation in 1848, was dominated by liberal politics through regional control in the cantons; the constitution of a united Switzerland 
was, in fact, the creation of liberal forces. ${ }^{91}$ This institutionalization of liberal politics was crucial in moving the Bundesrath in a direction that was consistent with the demands of business and banking in the mid- and late $1850 \mathrm{~s}$. One of these demands was the monetization of gold consistent with the French system.

Post-unification Italy in the 1860 s and early 1870 s was dominated by a liberal elite. The political system was an extension of Piedmonte's which had had a liberal constitutional system from the late 1840s. This essentially reflected Cavour's own political and economic leanings, which were strongly configured around the English example. Up until 1876 when the Left took power, leaders tended to be Cavour clones, reflecting both his political and economic agendas. ${ }^{92}$

The Scandinavian nations and Holland followed the Continental trend. Sweden saw the rise of liberal politics in the 1840s as a function of the political rise of a business class. As in France and Germany, liberals used this leverage to promote economic reforms. In Sweden the rise of liberal politics was especially pervasive, manifesting itself in the management of political, economic, judicial, and social systems. ${ }^{93}$ For Denmark, like Sweden, the 1840 s was also a crucial period in the growth of liberalism. Liberals became a national party in 1842 and by the late 1840 s gained significant influence in state assemblies. The 1840s also saw Christian VIII undertake extensive economic reforms. By the 1850 s the National Liberal Party came to dominate the Royal Council and the Landsting. ${ }^{94}$ In Holland 1848 proved to be a crucial political turning point. Led by Thorbecke, liberals imposed a constitution (on the government of William II) which reflected a middle-class political agenda and the system, consolidated under William III (1848-90), carried on a typically Continental style of economic policy. ${ }^{95}$ Holland also showed the same political dynamics over monetary issues that France had in the 1870s: a split between a Crown or executive which sympathized with silver versus a coalition of capitalist groups pushing strongly for gold. The reluctance to relinquish silver and bimetallist regimes de jure in these nations in the 1870s can be largely explained by a liberal lag in coopting the executive on monetary practices. ${ }^{96}$

Norway did not reflect the typical Continental timing in the transformation of politics, although the Norwegian political struggle was indeed typically Continental (liberal coalition versus a conservative government led by the Crown). Party politics remained relatively underdeveloped, and it was not until the mid-1880s that liberals and conservatives formed viable political parties. And although liberals gradually gained some power throughout the century, it was not until 1884 that they took formal control of the governmment. ${ }^{97}$ Much of this is explained by the fact that Norway did not experience the same socio-economic transformation that other
Continental nations did: it remained predominantly a small peasant farming economy throughout the nineteenth century. ${ }^{98}$

In the United States, the politics of money after the Civil War were coterminous with the politics of inflation. The monetary factions seemed to crystallize into three partly overlapping sets of opposing forces: by class, region, and party politics. With respect to class, the factions fundamentally mirrored the European style: stable money was the preference of an urbancapitalist class (commercial bankers, professionals, merchants, manufacturers, gentlemen reformers, respected literati) and was confronted by an inflationist-rural-agricultural class of farmers, landowners, and miners..$^{99}$ Regionally, the issue often split along a North and East (stable money) versus South and West (inflationist) cleavage. With respect to party politics, it was the "hard-money" Republicans versus "soft-money" Democrats. ${ }^{100}$ Unlike Europe, where the shift in monetary politics in favor of stable money was incremental, the shift in the US power structure emerged abruptly from the ashes of the Civil War which, by enhancing industrialization and sectionally polarizing party politics, created rigidities favoring stable-money interests in the American political system for the rest of the century. ${ }^{101}$

In sum, the politics of money, as a reflection of the greater political struggle within the developed world, showed that monetary issues were increasingly resolved in favor of a convenient and stable money, which by the end of the 1860 s and early 1870 s was equated with gold.

\section{The proximate foundations of the scramble for gold: chain gangs and regime transformation}

\section{The 1860s: A decade of growing nervousness}

The compelling structural changes in the developed world in the nineteenth century created an environment ripe for monetary regime transition after $1850 .{ }^{102}$ It was not until the late 1860 s and early 1870 s, however, that a structurally predisposed developed world encountered the proximate catalysts that consummated the transformation of monetary standards. These catalysts represented various critical events (which were principally coterminous with developments in the market for precious metals) that created and compounded nervousness over future trends in the value of silver.

The policy changes of the 1870s that demonetized silver were part of a common trend in the monetary history of the nineteenth century which saw nations protecting their monetary systems against disturbances in the market for metals. The gold strikes in the late 1840 s and 1850 s, for example, 
led to a depreciation of gold which caused Belgium, Spain, Naples, Switzerland, and Holland to protect their silver circulations by limiting gold convertibility. For similar reasons, Great Britain demonetized gold in India in the 1850s. ${ }^{103}$ The Act of 1834 changed the legal bimetallic ratio in the United States from 15:1 to $16: 1$ in order to abate a shortage of circulating gold coin resulting from a market bimetallic ratio that undervalued gold and overvalued silver at the mint. ${ }^{104}$ The Act of 1853 reduced the weight of small silver coins to abate the effects of the gold discoveries on silver circulation. ${ }^{105}$ Like other metallist monetary regimes, the regimes of the 1870s were thus subject to vagaries in the market for precious metals, but the constellation of policy responses of the 1870 s was far broader on a national level, and far more pervasive on an international level, than any similar phenomena before it.

The 1870 s version of this trend showed policy responses to the displacement of gold by silver in circulation owing to a depreciation of the latter metal. This reversed the pattern which had prevailed in the 1850 s and early 1860 s when the depreciation of gold led to the displacement of silver. By the late 1860s, with the movement of the market bimetallic ratio to a level which overvalued silver and undervalued gold at mints, it became profitable to import and coin silver, and melt and export gold. A continuation of this trend had two severe consequences. First, national monetary systems would be dominated by silver circulation, and gold would be scarce. Second, with the inflow of silver, nations would be on de facto standards based upon what John Sherman pejoratively referred to as a "depreciated currency" (1895, p. 541). Nations had difficulty tolerating the first, given their greater dependence on gold for larger-coin transactions. As for the second, a depreciating currency carried the possibility of multiple undesirable consequences: a depreciating exchange rate vis-à-vis gold-standard nations, depletion of international reserves (silver-standard nations would deplete their reserves when adjusting with nations on gold), and inflation. The stable-money monetary officials of the period were quite hostile to any such possibilities, especially inflation. ${ }^{106}$ Chevalier $(1859$, p. 201) noted that it was destabilizing for nations to shift (either de jure or de facto) to a standard "at the very moment when it is impaired in value and launched in a movement of depreciation."107

Like metallist regimes of the past, therefore, the regimes of this period were sensitized to developments in the market for precious metals. Given the strong structural predisposition toward gold, any developments in the supply and demand for metals that suggested a secular decline in the value of silver in the face of a stable or rising gold value, was the cause of grave concern. The worst-case scenarios portrayed the maintenance of silver and bimetallist standards when the decline in the value of silver was large, rapid, and secular. The nervousness over the market for metals became significant in the 1860s when the expressions of the preferability of gold over silver and bimetallist standards became pronounced, thus suggesting that a major shift in the demand for gold (whose value promised to rise) and silver (whose value promised to decline) was on the horizon. These expressions became more intense and international, and thus more visible, as the decade progressed, and with the visibility came a higher level of apprehension. ${ }^{108}$

At the national level, the calls for a legal gold standard were widespread. The Congress of German Economists and Chambers of Commerce (Handelsstag) had been advocating a gold standard in German states throughout the 1860s. Toward the end of the decade Prussian legislators, the German Customs Parliament, and various business groups (trade congresses) were calling for German membership in an international union based on gold. ${ }^{109}$ In 1869 a strong movement in Belgium arose to demonetize silver. ${ }^{110}$ Norway in 1869 began transforming its reserves from silver to gold. And in Sweden, a specially formed monetary commission in 1869 unanimously called for monetary union among Scandinavian nations based on a gold standard. ${ }^{111}$ French Chambers of Commerce and public opinion advocated a gold standard in France. ${ }^{112}$ Similarly, in Switzerland, commercial and banking groups, along with the various canton administrations and economists, strongly supported the move to gold. The Swiss National Council, in fact, interpreted the Act of 1860 which monetized gold as reflecting an intention to institute a gold standard in Switzerland. ${ }^{113}$

At the international level, there were two major gatherings of nations considering monetary union: the Latin Monetary meeting in 1865 and the International Monetary Conference of 1867 . The Latin meeting, which was originally called in response to disturbances in subsidiary silver circulation among the franc-bloc nations, ended up consummating a broader monetary union among France, Belgium, Switzerland, and Italy. The delegates of all four nations originally advocated union based on gold monometallism, with the French delegates eventually changing their preference to bimetallism after strict instructions from the French government. ${ }^{114}$ The Latin Union was founded on de jure bimetallism, but in actuality maintained a de facto gold standard by instituting a legal bimetallic ratio of $15 \frac{1}{2}: 1 .{ }^{115}$ While the Latin Union meeting was regional, that of 1867 was truly international (inviting 20 nations that represented the developed world at the time) and unanimously proclaimed gold monometallism as the only appropriate standard for economically developed nations. ${ }^{116}$ The Conference proved to be one of the more crucial events in convincing nations that a major disturbance in the market for metals was imminent. Monetary experts of the period and historians have identified the Conference as a fundamental turning point in the scramble for gold. According to Feer-Herzog, the 
Conference "sowed precious seed ... which the future would cause to germinate."117 For the US monetary diplomat Francis A. Walker "The Conference of 1867 , in proclaiming the crusade against silver ... did [initiate the demonetization of silver], the consequences of which are even yet only half unfolded."118 As a direct consequence of the Conference, the Bank of Norway, for example, was authorized to change its reserves from silver to gold. ${ }^{119}$ The Conference also proved to be a principal catalyst of Germany's movement to gold. Its proclamation of an impending monetary transformation in the developed world made a German transformation seem ever more necessary in the Reichstag because of the large amount of silver in German states which would have to be liquidated. 120

In addition to the proliferation of appeals for a legal gold standard, developments in India also bode poorly for the future of silver. India had emerged as one of the principal silver markets in the world. Indian silver imports relative to world production exhibited an enormous increase after. 1854. From 1855 to 1865 , with the exception of the year 1860 , yearly Indian net imports of silver were either greater or slightly below the entire yearly production of silver in the world. (The net imports in 1865 were almost twice the world production of silver.) ${ }^{121}$ The period $1866-70$ saw a decline in yearly net silver imports relative to world production to levels lower than the quinquennial imports of 1856-60 (see table 2.1). ${ }^{122}$ Even though the price of silver showed little immediate sensitivity to shifts in Indian demand, these developments presaged difficult times for silver in the future because the conditions leading to a lower demand for silver were not perceived as reversible. ${ }^{123}$ First, with the return of US cotton onto the world market, Indian exports would never again reach the levels achieved in the years 1861-65. Furthermore, less silver was flowing into India because of an increasing use of council bills to clear payments, a practice which was expected to continue in the future. ${ }^{124}$ It became apparent that the decline of one of the world's largest markets for silver might be secular rather than cyclical, given that significant changes in net silver imports before 1860 were never the result of systematic uses of new financial instruments.

On the supply side, the production of silver had been secularly increasing from the second decade of the century, with especially large increases after $1850 .{ }^{125}$ The average yearly increases from the period 1856-60 to that of 1861-65 and from 1861-65 to 1866-70 were both 22 percent. Even in the latter quinquennia, however, the average yearly increase from the previous quinquennia was still well below the average yearly net imports of silver into India. ${ }^{126}$ But aside from contributing to a mild decline in the price of silver in the late $1860 \mathrm{~s}$, the increase added more concern about the market for metals, especially in light of the fact that the production of gold during the 1860 s was declining. Gold production declined from the middle to the
Table 2.1 Silver: net imports into India and world production, 1851-79

\begin{tabular}{|c|c|c|c|}
\hline Year & $\begin{array}{l}\text { Net imports of } \\
\text { silver into India (1) } \\
(000)\end{array}$ & $\begin{array}{l}\text { World production } \\
\text { of silver }(2) \\
(000)\end{array}$ & $\begin{array}{l}\text { Net imports as } \\
\text { a percentage of } \\
\text { world production }\end{array}$ \\
\hline 1851 & $\$ 14,327$ & \multirow{7}{*}{$\$ 39,875$} & 36 \\
\hline 1852 & 23,025 & & 58 \\
\hline 1853 & 11,529 & & 29 \\
\hline 1854 & 148 & & $<1$ \\
\hline 1855 & 40,972 & & 103 \\
\hline 1856 & 55,366 & & 136 \\
\hline 1857 & 61,095 & & 150 \\
\hline 1858 & 38,641 & \multirow[t]{3}{*}{40,725} & 95 \\
\hline 1859 & 55,738 & & 137 \\
\hline 1860 & 26,640 & & 65 \\
\hline 1861 & 45,432 & \multirow{5}{*}{49,550} & 92 \\
\hline 1862 & 62,751 & & 127 \\
\hline 1863 & 63,984 & & 129 \\
\hline 1864 & 50,394 & & 102 \\
\hline 1865 & 93,343 & & 188 \\
\hline 1866 & 34,815 & \multirow{5}{*}{60,250} & 58 \\
\hline 1867 & 27,970 & & 46 \\
\hline 1868 & 43,005 & & 71 \\
\hline 1869 & 36,602 & & 61 \\
\hline 1870 & 4,710 & & 8 \\
\hline 1871 & 32,564 & \multirow{5}{*}{88,625} & 37 \\
\hline 1872 & 3,523 & & 4 \\
\hline 1873 & 12,257 & & 14 \\
\hline 1874 & 23,211 & & 26 \\
\hline 1875 & 7,777 & & 9 \\
\hline 1876 & 35,994 & \multirow{4}{*}{112,500} & 32 \\
\hline 1877 & 73,382 & & 65 \\
\hline 1878 & 19,853 & & 18 \\
\hline 1879 & 39,349 & & 35 \\
\hline
\end{tabular}

Notes:

1. Estimates in Report to House of Commons, 1876 and French Report of Conference of 1881, both reprinted in Laughlin (1886, pp. 252, 253)

2. Soetbeer's estimates, reprinted in Laughlin (1886, p. 218). 
end of the decade, and total decadal production in the 1860s was 7 percent lower than production in the 1850s. These differential trends in supply promised to compound the effects of prevailing demand conditions in moving the values of gold and silver in directions that would threaten national gold supplies. And, in fact, the latter half of the decade saw the price of silver dip and remain below 61ppp, and the market bimetallic ratio move from a level that was below the legal ratio in Latin Union nations (thus encouraging a large gold circulation because gold was overvalued at the mints) to one that was above the legal ratio (thus threatening to drive gold out of circulation). ${ }^{127}$

In sum, the latter half of the 1860s witnessed the emergence of a nervousness over conditions prevailing in the market for metals. The principal concerns centered around supply and demand conditions that carried important consequences for monetary standards, and these conditions tended to be perceived as permanent rather than transitory. Gold would continue to dominate larger-coin transactions, the Indian market for silver was declining, and monetary authorities were compelled by the practice of gold monometallism. Critical events embodied in national and international proclamations of the superiority of gold monometallism as a standard for developed nations were perceived to carry important secular demand consequences. In the short run, the supply of precious metals showed an increase in the production of silver and a decline in the production of gold, the price of silver was declining, and the market bimetallic ratio was moving above the legal ratio prevailing in the bimetallist nations of Europe. It became commonly perceived that the world was moving toward conditions which would make it impossible concurrently to circulate silver and gold at par, and that any such attempts at concurrent circulation under the traditional practice of a fixed legal ratio would result in a scarcity of the most convenient metal: gold. Furthermore, any nation remaining on a silver standard would be faced with the possibility of a depreciated currency. In a fundamental sense, the 1860 s initiated a contraction of the metallist menu in the eyes of monetary authorities. With prevailing conditions increasingly delegitimating the practices of orthodox bimetallism (i.e., with a fixed legal ratio) and silver monometallism, the choice was converging toward gold.

But as the decade ended no significant policy initiatives had been enacted that would legally eliminate silver as a central monetary unit, or significantly limit the convertibility of silver. Latin Union nations were still legally bimetallist, as was the United States, which was continuing a suspension of convertibility. Sweden, Denmark, Norway, Holland, and Germany were legally on silver standards. As long as the value of silver had only depreciated slightly and mints remained open, fears of gold depletion and floods of silver were not overwhelming. This created a holding pattern in the late 1860 s. Critical developments in the 1870s would turn this disposition of "watchful waiting" into a scramble for gold.

\section{The monetary chain gang}

In terms of pervasive economic policy changes, the transition to gold in the 1870 s was relatively rapid. The decision to move to gold monometallism had been consummated in Germany and the Scandinavian nations by the end of 1872. For members of the Latin Union the transition was initiated in 1873-74, first with the limitation on the coinage of 5-franc silver pieces in Belgium and France in 1873, and then with the institution of limits over the entire membership of the Latin Union in $1874 .{ }^{128}$ Holland limited the purchase of silver ingots at the Netherlands Bank in 1872 and temporarily suspended the coinage of silver in 1873. The United States was still on a paper standard, but did legally demonetize its central silver coin in 1873 and further marginalized silver by instituting a regime of limited silver coinage with the Bland-Allison.Act of 1878. It thus took three years from the time Germany moved to gold in 1871 for all these nations to eliminate silver as a central monetary metal.

This speed was a natural outcome of conditions that created a monetary "chain gang" among these nations: the movement of any one or a few nations to gold in this period of nervousness would assure that the others would follow suit. The chain gang structure of monetary policy emanated from two types of interdependence. The first I refer to as speculative interdependence; the second was of a monetary and trade nature.

As for speculative interdependence, conditions in the market for silver in the late 1860 s and early 1870 s were functionally similar to conditions in markets which find themselves at the height of a speculative boom (i.e., bubble), where investors are holding assets or commodities whose values are threatened with sharp and rapid declines. The liquidation of assets or commodities in such markets at what is considered a peak is typically one of contagious liquidation or "running with the herd," where one or two significant liquidations will create an urgency for other investors to follow. ${ }^{129}$

Monetary experts of the period described the late 1860s and early 1870s as a period of "alarm and apprehensions" and even "panic" over developments in the market for metals that could have grave consequences for national monetary systems. ${ }^{130}$ Any compelling signs that market conditions were turning against silver, either by a sharp decline in its value or crucial events (like legal changes in monetary practices) that signalled an impending decline, created a sense of urgency to pre-empt others in 
demonetizing silver, or to follow closely behind the demonetization initiatives of other nations. Any lag was considered with the greatest concern. Feer-Herzog's description of a common perception shortly before 1871 is representative:

There are two milliards of silver in Germany and Austria demanding that they be converted into gold, because the states that possess them are resolved to adopt the gold standard. The state that demonetizes first will do so with but little loss, while the state which shall have hesitated and waited will undergo the losses resulting from the demonetizations which have preceded its own, and so will pay for all the rest. The German authors have perfectly understood . . . the advantages which will accrue to their country from acting speedily ... ${ }^{131}$

From the late 1860 s, both France and Germany acknowledged the advantages of pre-empting others onto gold and the disadvantages of lagging behind. France, as noted, was prevented by the deft political maneuvering of the Ministry of Finance, but defenders of gold in the French Monetary Commission of 1869 stressed that the North German states were committed to gold, and that France dare not delay its transition in a world which appeared on the verge of a scramble. Germany's own movement to gold was formulated in an environment in which monetary authorities accepted the inevitability of a global movement toward gold, and were therefore more disposed toward a strategy of early transition. ${ }^{132}$ Sumner's assessment of the scramble of the 1870 s noted that as soon as nations became convinced of the inevitability of a widespread transition to gold and away from silver (thus assuring a declining value of silver), "they seemed to be running over one another's heels as fast as they could to get rid of silver, because the one who sold first would get the best price."133

The chains linking the monetary standards of nations were strengthened by trade and monetary interdependencies which created greater urgency to monitor and respond to changes in the monetary practices of other nations Nations were concerned with keeping uniformity in their standards so as not to disturb trading relations with their principal partners. ${ }^{134}$ Holland would have found it extremely difficult to sustain a silver standard once Germany and Great Britain, its two major trading partners, were both practicing gold standards. The Dutch monetary diplomat Mees stated that as long as Holland stood between Germany and Great Britain financially and geographically, she must conform to their monetary practices. ${ }^{135}$ In the United States, it was acknowledged in elite monetary circles that the movement to gold by the major trading nations of the world necessitated a gold standard. ${ }^{136}$ From the 1870 s onwards John Sherman (1895, pp. 470, 1190 ) continued to argue against central monetary status for silver on the grounds that such a practice would "detach the United States from the monetary standards of all the chief ... nations of the world ... with which [the United States had its] chief commercial and social relations." In France there was grave concern over carrying on exchanges with the "great commercial nations" in a depreciated currency. ${ }^{137}$

In the greater constellation of developed nations that made transitions to gold in the 1870 s, trade and monetary dependence most visibly manifested itself in two economic "satellite" systems: (1) Germany and its Northern European satellites (Sweden, Denmark, Norway, and Holland) and (2) France and its principal Latin satellites (Switzerland, Belgium and Italy). Each of these satellite systems itself formed a small monetary chain gang centered around the monetary and trade hegemony of Germany and France. Within these systems the monetary policies of hegemonic economies were compelling: any changes in monetary practices in the core were quickly exported to the satellite economies. Germany's Northern satellites stayed historically close to German monetary practices principally due to trade dependence; they, like Germany, were on silver standards before the $1870 \mathrm{~s}$. At the International Monetary Conference of 1867 , the Norwegian delegate Broch made it clear that given Norway and Sweden's dependence on their trade with Northern German states (especially Hamburg), any decision these nations reached on a monetary standard must be conditional upon Germany's selection of the same standard. ${ }^{138}$ M.J. Cramer, a US diplomat reporting on the monetary situation among Scandinavian nations following Germany's move to gold in 1871, identified an overwhelming perception that because of Germany's new standard, "a corresponding change in the money system of the Scandinavian North had become an absolute necessity." 139 Holland, too, as noted, found the German move compelling. ${ }^{140}$ Compounded by an already large British trade, the Northern nations found themselves in a bloc whose monetary practices were essentially contingent upon the preferences of Germany. The Scandinavian Monetary Union and monetary legislation in Holland were strong manifestations of Germany exporting her monetary standard onto economically dependent nations. ${ }^{141}$

The Latin Union nations showed the same historical conformity in monetary standards. The Union's formation in 1865 merely consolidated an already existing monetary bloc (the franc bloc). ${ }^{142}$ In fact, Switzerland, Belgium, and Italy inaugurated the monetary systems of their newly unified or independent nations based exactly upon the French system as legislated in the Law of 1803. In Belgium's case, the Law of 1832 inaugurating a monetary policy was a "word for word" recreation of the French Law of 1803. ${ }^{143}$ By the 1860 s, monetary and trade dependence within the Latin constellation had grown so as to preclude any significant deviations from French monetary practices. ${ }^{144}$ The Swiss monetary diplomat Kern's state- 
ment putting forward his nation's position on monetary unification at the International Monetary Conference of 1867 is representative of the fate of Latin satellites. He said that Switzerland itself preferred union based on a gold standard, but that its ultimate decision would be dictated by the preference of France. ${ }^{145}$ The Latin Union found itself in a situation in which "as soon as France gave up its double standard and accepted the gold standard ... [i]t was certain that Switzerland, Belgium, and Italy would express their absolute adherence to such a step."146

The late 1860s and early 1870s thus found the developed world in a nervous environment and configured in a structure of monetary and trade interdependence that dictated a conformity in monetary practices. Such a situation was ripe for a transition onto gold en bloc once the holding pattern of the 1860s had been broken by critical developments in the 1870 s which increased the urgency of demonetizing silver.

\section{The 1870 s}

Nations that adopted de jure gold standards in the 1870s did nothing but legally sanction that which they had been practicing throughout the $1850 \mathrm{~s}$ and 1860s. Values in the market for metals in these decades had been such that gold had displaced silver in circulation (gold was overvalued and silver undervalued at mints). No laws protecting gold circulations were necessary until market conditions changed so as to encourage the displacement of gold. But the overvaluation of gold and undervaluation of silver at mints by the late 1860 s was still moderate, and as yet there were no definitive national commitments on the part of major economic powers that threatened the convertibility of silver. The 1870 s changed these conditions of watchful waiting into a more intense nervousness. The period of greatest apprehension was initiated by Germany's legal adoption of a gold standard in 1871: Germany's transition can be regarded as the unilateral policy initiative that pulled the monetary chain gang onto gold. ${ }^{147}$

Of the nations that eventually made the transition onto gold after 1870 , Germany was perhaps the most structurally predisposed. Pro-gold ideology was most developed in Germany's elite monetary circles. The agitation of interest groups calling for monetary practices better adapted to industrializing economies was most visible in Germany, and politics were strongly conducive to a gold policy given Bismarck's sensitivity to the liberal economic policy agenda. At the proximate level, Germany was anxious not to lag behind a Continental monetary transformation that it perceived as inevitable, ${ }^{148}$ and the large inflows of silver in 1871, according to Helfferich $(1927$, pp. 155, 156), wiped out whatever uncertainty still remained in Germany about the exact course of monetary unification. The swelling silver circulation directly led the government to institute a reduction in the purchase price of silver at the Berlin mint (the largest in Germany). When this failed to abate the influx of silver, the purchase of silver from private persons was suspended at the mint. As Helfferich (1927, p. 156) noted, the exact legislation of monetary unification was now "prejudiced by the pressure of events." 149

The German move had both immediate psychological and real impacts on its Northern satellites. These nations immediately faced significant influxes of silver. ${ }^{150}$ In 1872 a Joint Scandinavian Monetary Commission was formed to consider the monetary question following Germany's transition to gold. The report of the Commission established the foundations of the Scandinavian Monetary Union. It recommended that these nations follow the German policy and institute gold standards. In December 1872 a convention founded on the report was signed by Norway, Sweden, and Denmark. By 1873 all three nations had gold standards. Denmark and Sweden immediately became members of the Union, with Norway deferring membership (but remaining on gold) until $1875 .{ }^{151}$ In Holland, the German action caused the King immediately to appoint a monetary commission to consider the question of an appropriate standard for Holland in the wake of the new monetary conditions. The commission concluded that the silver standard had become untenable given the direction of monetary developments in the world. It cited the double standard as theoretically best, but said that it was not possible unless Germany instituted such a standard. It recommended that silver coinage be suspended. In December 1872, the Netherlands Bank stopped purchasing silver; a law instituting a temporary (six-month) suspension of silver coinage was enacted in $1873 .{ }^{152}$

The fall of the German chain gang from silver was consummated by 1873. Fears of the scenario which had gained international attention with the International Monetary Conference of 1867 were beginning to be realized. The world was demonetizing silver: the convertibility of silver on a global scale was becoming restricted as Continental mints were closing. Moreover, the entire net silver imports into India from 1870 to the beginning of 1873 were barely more than they had been in the single year of 1869 , and they were approximately half the net imports of the year 1865 . Except for the years 1847-49 and 1854, net imports in the year 1872 were the lowest of the century up to that time (see table 2.1). The precipitous decline in Indian silver demand in the 1870 s was the source of even more pessimistic expectations about the future demand for silver.

On the supply side, the early 1870 s experienced a significant increase in silver production and an equally significant decline in gold production. The increase in silver production from 1870-71 was the single biggest one-year 
increase of the century (roughly 20 percent by most estimates). ${ }^{153}$ Moreover, it was believed that the mines in the United States were still short of their highest yield potential. ${ }^{154}$ The following year saw the most significant one-year decline in gold since the 1850 s. $^{155}$ Especially compelling were fears of the supply consequences of Germany's move to gold. ${ }^{156}$ Throughout the 1870 s the German silver supply was perceived as a major proportion of an increasing global pool of silver chasing fewer and fewer buyers as nations closed their mints. ${ }^{157}$ Fears of what France's Léon Say referred to as Germany's "enormous mass of silver ... [being thrown] upon the metal market" permeated the decade. ${ }^{158}$

By 1873 the course of events had brought market conditions to a state that put intense pressure upon Latin Union nations, which until this time were still in a holding pattern. In 1872 the price of silver breached two important thresholds. On the London market it had dropped below 60ppp for the first time since $1849 .{ }^{159}$ In September 1873 the market bimetallic ratio hit the 16:1 level for the first time since April 1845. ${ }^{160}$ The resulting influx of silver and outflow of gold from Latin Union nations assumed "alarming" proportions. ${ }^{161}$ The net imports of silver into France in the first three months of 1873 alone reached 52 million francs. Net gold exports more than doubled from 105 million in 1872 to 225 million francs in 1873 , and assumed an amount which was greater than one-third of the gold holdings of the Bank of France in 1873. In the years 1872 and 1873, with the exception of Italy, no gold was coined in the Latin Union. The total silver coinage of France and Belgium went from 26,838,370 francs and $10,225,000$ francs respectively in 1872 to $156,270,160$ and $111,740,795$ in 1873. Italy experienced only a 20 percent increase in silver coinage. ${ }^{162}$ Switzerland continued its policy of coining little of its own money, but found the influx of silver and the outflow of its foreign gold coin destabilizing. Monetary conditions could not continue in this situation.

Agitation was strong in both Belgium and France to check this unfavorable flow of metals. Belgium was the first among Latin Union nations to begin unilateral action in response to the alarming developments of 1873 by reviving early in that year an old decree (of 1867) that limited the daily coinage of silver to 150,000 francs for the public and an equal amount for the National Bank. Calls for stronger measures followed and the Ministry of Finance addressed the question to a group of monetary authorities, which declared that the Latin Union should move to a gold standard. A law quickly followed empowering the government to limit or suspend the coinage of 5-franc silver pieces until January 1, 1875. France in September 1873 instituted a limit on silver coinage up to 250,000 francs per day (lowered to 150,000 in November). In that same month the Bank of France stopped making advances on deposits of silver bullion, and practically refused to accept Belgian and Italian 5-franc pieces for deposit. These measures, especially the limitations on coinage which were secret, did little to stem the speculation in France. ${ }^{163}$

A collective Latin Union response to the problem became inescapable, and in November 1873 the Swiss issued a request to the French government to convoke a Latin Union meeting to form a new regime based on gold. The request was founded on a shared belief that since Germany and her Northern European satellites were adopting gold, it would be "folly" for Latin Union nations to continue their present policy of bimetallism. ${ }^{164}$ The meeting of the Latin Union in January 1874 led to the institution of yearly limits on the coinage of the Union's central silver coin, the 5-franc piece. The limits placed Latin Union nations in a somewhat safer holding pattern from which trends in the market for metals could be assessed before determining an optimal long-term standard for the Union. ${ }^{165}$ The measures resulted in a greater flow of gold into Latin Union nations, thus granting some relief, although in France, net silver imports in 1874 were substantially larger than those in $1873 .{ }^{166}$

In Holland the temporary suspension of silver coin instituted in 1873 ran out in May 1874, and the Utrecht mint was again open to silver purchase. The resulting flood of silver into Holland forced the government to once more suspend silver coinage in December of that year. ${ }^{167}$ The pressures to make a more complete transition to gold became especially intense in this period as a suspension of convertibility caused the gulden to depreciate significantly. It was also obvious that as long as market conditions remained the same or worsened, conventional silver and bimetallist standards were not feasible. In June 1875 Holland established a gold (10gulden) coin and continued the provisional suspension of silver until December 1877, when suspension was made definitive, thus formally instituting a gold standard. ${ }^{168}$

The Latin Union met again in 1875 to adjust the limits agreed upon for the coinage of 5-franc pieces in 1874 . The holding pattern was still viable as a favorable movement of gold which resulted from these measures continued, ${ }^{169}$ but it was clear that market conditions were worsening as the value of silver continued to fall. The decline in the price of silver in London was now dramatic. It dropped from $58 \frac{5}{16} \mathrm{ppp}$ in 1874 to $56 \frac{7}{8} \mathrm{ppp}$ in 1875 , and the market bimetallic ratio pushed to its highest level of the century, 16.62:1. Indian net silver imports were well below 1874 levels. The belief that the depreciation of silver was not a cyclical but a secular phenomenon became more compelling, and monetary authorities began to look for a more definitive standard for the Union. ${ }^{170}$ The urgency to move to gold was enhanced by an even more drastic decline in the value of silver in 1876 . In July the London price had actually been quoted as low as $46 \frac{3}{4} \mathrm{ppp}$, and 
the market ratio in that month had surpassed the 19:1 level. Following another adjustment of the Latin Union coinage quotas in early 1876, the silver question finally reached the French Chambers. ${ }^{171}$ The result was a law in August of that year suspending both the coinage of 5-franc pieces at the French mint and the further reception of bullion for deposit. ${ }^{172}$ The influx of gold into France from both Union and non-Union nations now accelerated. Belgium responded to France's policy and her loss of gold to France with a law in December providing for complete and indefinite suspension of the 5-franc piece. This policy was extended de jure to the Union as a whole in 1878. ${ }^{173}$ The lag in the Union's formal adoption of gold reflects the asymmetrical interdependence in the Latin Union system. The main force behind the lag was France, whose own preference for watchful waiting through the turbulent market conditions of the $1870 \mathrm{~s}$ reflected the economic policy agenda of the Ministry of Finance and haute finance. Satellites were calling for gold as early as 1865, and once France formally fell into the gold club in 1876, its Latin Union allies followed closely behind.

The United States was more removed from this specific monetary turbulence of the 1870 s, as it continued on an inconvertible paper standard. Events on the Continent thus did not elicit immediate responses. The US policy evolution toward gold in the 1870s was not of the drastic-reactive type seen in Europe. It was a less frantic and more reflective response to compelling developments in the United States and the world. Above all, elite concerns gravitated around resuming convertibility with a viable longrun standard. Much of the input into decisions underlying monetary options were considerations of trends in Europe and the general movement of market conditions for precious metals. The management of the money supply and monetary institutions in the United States in the 1860s and 1870 s were configured around stable-money preferences. Behind much of the hard-money assault on bimetallism were fears over events in Europe and prevailing global market conditions. The principal fear centered around secular trends in the world creating a "depreciated currency" in a bimetallist United States. ${ }^{174}$ Behind the Allison revisions of the Bland Bill of 1877 were sensitivities to the perils of resuming specie payments on bimetallism in a world bent on gold. Allison warned about the growing demand for gold in Europe and the destabilizing flows of silver into France. He affirmed the folly of being the only nation to open its doors to silver in a world which was frantically redeeming its excess silver to increase gold circulations. Each of the concerns manifested itself in the final BlandAllison Act of 1878, which assured resumption on a gold standard. ${ }^{175}$ Although the pull was milder, the United States also followed the chain gang onto gold.
By the late 1870 s with the transition to gold consummated, any unilateral initiatives toward silver or bimetallist standards were seen as impossible. Like a Prisoner's Dilemma game in a non-cooperative Nash equilibrium, any unilateral move toward cooperation (opening mints to unlimited silver coinage) exposed the cooperating nation to exploitation. The new open mints would be a tempting target for the mass of silver on the world market, as the Dutch experiment of 1874 had showed. ${ }^{176}$ With the rapid decline in the value of silver and the now irresistible conviction that silver qua central monetary metal was at a point of no return (barring some grand international agreement), the potential flood of silver was expected to be devastating. Sherman's concern for the United States (1895, p. 541) was felt by all recent converts to gold. "The general monetizing of silver now ... would be to invite to our country, in exchange for gold or bonds, all the silver of Europe."177 Nothing better characterized this strategy than France's "expectant policy." It dictated that French policy would follow upon the initiatives of the community of developed nations in any attempt to stabilize the price of silver. In essence, it committed France to being a follower, not a leader. ${ }^{178}$ All nations still sympathetic to bimetallism (the United States, Holland, France, and Italy) shared this view. Any movement back toward silver would have to be en bloc.

The International Monetary Conference of 1878 , convened by the United States as a mandate of the Bland-Allison Act, gave the world a viable forum to discuss the resuscitation of silver. But it was doomed at the outset. Germany would not consider a change in monetary standards, it refused even to attend the Conference; this automatically froze its Northern European satellites' position. Since the threat of Germany's large silver pool persisted, France would not resume her old policy of silver convertibility. Great Britain reiterated its commitment to gold. And the United States would consider a bimetallist standard only if it were part of an international agreement, which was not forthcoming. The Conference failed. With its failure fell the final curtain on the silver question. The metal which had dominated exchanges for centuries was reduced to token status. In the words of Ludwig Bamberger, it was the "dethroning of a worldmonarch."179

When the scramble for gold began in the first years of the 1870s, it was as much a psychological as a real phenomenon. When Germany turned to gold, market conditions were far from intolerable. The price of silver had declined little, Indian silver demand was only then beginning its precipitous drop, and mints on the Continent remained open to silver. Germany's own move appeared to be structurally driven, with the anticipation of a Continental scramble and some market disturbances enhancing the urge toward gold. Political unification conveniently appeared as a means of realizing its 
monetary predispositions. Germany's Northern satellites were driven by the anticipation of adverse consequences on their trade relations with Germany, as well as disturbances in the flow of precious metals. From 1873 on, however, market conditions became intolerable for any mints fully open to silver. Latin Union nations found themselves deluged with silver, and Holland's experiment with silver-convertibility resumption in 1874 failed. What was at first driven by cognitive dispositions (i.e., pessimistic projections about conditions in the market for metals) became exclusively sustainable by real conditions as the decade progressed.

There is no question that self-fulfilling prophecy manifested itself in the scramble, specifically in the nervousness of the late 1860 s and early 1870 s which contributed to the sharp decline in the value of silver in the 1870s. ${ }^{180}$ It is clear, however, that the market itself was in the midst of secular trends that augured poorly for the value of silver. Gold production showed a declining trend after the 1850 s, which was to continue until the 1890 s. Silver production had been secularly increasing across the century, especially sharply after 1850. Also, with the passing of the Civil War and the increasing use of council bills, India would never again be the market for silver that it had once been. Compounding these market conditions were, of course, the structural factors driving nations away from silver. The changing nature of economic exchange made silver increasingly archaic as a medium of exchange for large transactions. Growing trade and the internationalization of finance enhanced the desirability of emulating the British standard, which continued to generate appeal on ideological grounds. Shifting political structures created a more hostile environment against an inconvenient and inflationary metal like silver. ${ }^{181}$ It is therefore apparent that, self-fulfilling prophecy notwithstanding, the transformation of monetary regimes after 1850 was irresistible: self-fulfilling expectations merely hastened an inevitable outcome. Structural and market forces had brought the developed world to a state where any significant real and/or psychological disturbances which threatened national gold circulations would bring about the demonetization of silver.

\section{Conclusions: the gold standard and monetary regime theory}

As with most broad overviews of historical trends comprising the actions of many nations, this study aspires more to the illumination of important forces that played a role in the scramble for gold, than definitively to model the correlates of monetary practices in that period. The latter would require a detailed study of the nations that did not join in the scramble for gold (i.e., those that maintained silver-based and paper standards). Although such an enterprise lies beyond the scope of this study, some pertinent observations can be offered. It is apparent that the scramble for gold was essentially a phenomenon that characterized the developed world (Western Europe and the United States). With some exceptions, nations outside of the developed world tended to remain on non-gold standards. This is consistent with the logic in this study. First, the more numerous and larger transactions in developed nations made gold more attractive as a medium of exchange, while countries with lower incomes did not find silver as inconvenient. ${ }^{182}$ Second, the change of political structures which redistributed power from high-inflation groups (agricultural interests) to low-inflation groups (urban-capitalists) was more pronounced in economically advanced nations. The underdeveloped world (where silver and paper retained their central positions) featured more traditional political power structures. Finally, it may be the case that monetary status was a necessity for the developed world, while it was only a luxury for less-developed nations. Developed nations may have felt more pressure to conform to the practices of leading nations. Ford, for example (1962, p. 134), notes how Argentina did not feel the same shame that Great Britain would have felt in breaking the gold link, while Keynes ([1913] 1971, p. 5) observed that when the Reichsbank found it necessary to limit convertibility, it did so "covertly and with shame."

These observations, however, are not free of anomalies. Portugal, a relatively underdeveloped nation with traditional political structures, preempted other Western European nations onto a de jure gold standard. ${ }^{183}$ Austria-Hungary and Russia in the 1890s also made the gold link in the face of traditional political structures which resisted fixing the exchange rate. ${ }^{184}$ Argentina resumed gold convertibility in the twentieth century under the leadership of landed oligarchs. ${ }^{185}$ Italy, although following the Latin Union onto a de facto gold standard in 1865 , found it necessary to break the gold link in 1866 and resume it again in 1884. And Spain, of course, did not conform to the behavior of its Western.European neighbors in the 1870s.

These anomalies and the case studies in this chapter suggest first that additional factors need to be imputed into any comprehensive explanation of the selection of monetary standards in this period, and second that greater attention needs to be paid to the relative influence of each factor. Some nations found it easier to follow the structural-proximate compulsion and formally adopt gold standards. In this respect, there appear to have been permissive factors which influenced to what extent structural and proximate catalysts could dictate the choice of a monetary standard. Permissive factors such as the development of capital markets and central banking institutions, and the management of money supplies and fiscal policies played important roles in determining whether nations could 
successfully institute and maintain the gold link. Nations with more developed capital markets and central banking institutions, and which practiced fiscal and monetary restraint (i.e., low inflation and low budget deficits) found it easier to institute and maintain a gold standard. These permissive factors need to be more fully identified and understood. ${ }^{186}$ Assessing the relative influence of each factor was difficult in these case studies because the structural and proximate forces usually tended in the same direction. More definitive conclusions about relative influence in causation could be generated by carefully considering crucial cases (e.g., cases in which two factors encouraged different responses). ${ }^{187}$

Notwithstanding these limitations, the findings of this study carry some important implications for the study of monetary regimes. As a process of regime transformation through multiple evolutions in national monetary standards, the scramble of the 1870 s represented the culmination of a shrinking monetary menu. By the 1870 s, structural and proximate forces had eliminated silver from the list of viable long-run standards in the developed world. Whatever superiority paper possessed over gold with respect to convenience was strongly counteracted by the stable-money and metallist orientations prevailing among monetary authorities of the period. Gold won by default. In the study of comparative political and economic systems, this convergence in monetary institutions is indeed unique. Nations rarely face such restricted options in confronting regime disturbances. As Gourevitch (1978, p. 911) notes, "some leeway in [policy] response is always possible." Although silver politics in the United States. and the strategic political coups of the French Ministry of Finance were successful in providing some of this "leeway" in the short run, the course of monetary events was compelling. The growing redundance in monetary practices is attributable to the fact that nations were exposed to a common set of internal and external forces. Moreover, these forces were homogeneous (i.e., complemented each other) with respect to their influence on the choice of monetary standards. ${ }^{188}$ To borrow an analogy from Wolfers (1962), the developed world found itself in a burning house with a single exit. In terms of theories explaining comparative monetary regimes, the gold standard demonstrated that when comparative regimes are exposed to international environments which generate common and homogeneously influential forces, the likelihood of uniformities in rules and institutions will be high.

The scramble for gold also demonstrated that the proliferation of common national responses to disturbances is especially rapid among groups of nations that are highly interdependent. The monetary chain gangs which prevailed in the nineteenth century made an en bloc response to the depreciation of silver inevitable. Trade and monetary interdepen- dence were keenly felt among core nations, especially in the satellite systems that crystallized around the economic hegemony of France and Germany. These cases suggest that domestic monetary regimes can more easily transmit themselves internationally in constellations of interdependent nations. The sensitivity shown in the French and German satellites is not unlike that which we see today in pegging blocs where key currency nations essentially export their monetary policies to trade-dependent satellites.

In terms of the interconnections between domestic regimes, common developments in monetary practices in this period were influenced by transformations in both political and economic systems. The gold standard, therefore, attests to the endogeneity of monetary institutions. The fundamental structure of economic exchange and production shifted to one which required a more "cosmopolitan" standard. The political rise of urban-industrial society encouraged a monetary standard that facilitated exchange and encouraged stable money. Interestingly, the monetary orientation of politics has changed over the last century, from one of stable money to one of inflation. With the politicization of the budget (through the rise of the welfare state) and the electoral impact of unemployment, inflation has become a fundamental means through which elites gain and maintain office. ${ }^{189}$ Those advocating a shift in monetary policies away from the inflationary fiat regimes of today should take special note of the interconnections between politics and money. Any such policy shift would have to overcome very strong political rigidities.

Finally, the scramble for gold showed that the convergence of monetary practices at the domestic level can generate a regime at the international level. The confluence of structural and proximate forces influencing monetary practices in this period did what none of the four major international monetary conferences after 1850 could do: create uniformity in the monetary standards of developed nations. Nations failed to bring a gold union about through multilateral managerial initiatives. And unilateral managerial (i.e., hegemonic) initiatives were not attempted. In this case, the formative process was diffuse rather than centralized. ${ }^{190}$ The scramble for gold showed that monetary hegemony and broad multilateral cooperation are not necessary conditions for the creation of international regimes. Consequently, social scientists should consider more than hegemonic intentions and the use of power when explaining the processes through which international monetary institutions emerge. Furthermore, the diffuse nature of the international gold standard suggests that we can sometimes learn as much about international relations from studying prevailing domestic developments among nations as we can from observing the direct interactions between them. 


\section{Notes}

I gratefully acknowledge the comments of Michael Bordo, Forrest Capie, Jeff Frieden, Richard Grossman, Philip Pomper, Jaime Reis, and Anna Schwartz.

1 Keohane (1984) and Young (1982).

2 See, for example, Campbell and Dougan (1986) and Dorn and Schwartz (1987).

3 Economists are more likely to think of monetary regimes in terms of the rules governing the money supply, while this study looks at broad changes in monetary standards as constituting a regime transformation. Although the two are distinct, we should remain sensitized to the possible interdependencies between them. Being on one standard or another may carry consequences for the outcomes which monetary policy aims at, such as stability in exchange rates or inflation. In fact, in this period much of the political battle between silver and gold revolved around different expectations about inflationary consequences of selecting a standard.

4 Martin (1973) and Laughlin (1886, pp. 79-85) see 1853 as the real end of bimetallism given that the monetary legislation of that year failed to make coinage adjustments that would bring the silver dollar (which had disappeared owing to a higher intrinsic than nominal value) back into circulation, and followed up this so-called (by silverites) "neglect" with a further marginalization of silver coin through changes in weights and legal tender regulations.

5 Willis (1901) and Redish (chapter 3 in this volume). Italy was the only exception, being allowed to coin a limited amount of pieces the following year

6 This could also be said of the United States by the late 1870s.

7 By 1885 there was not a mint open to the unlimited coinage of silver in Europe and the United States. See Laughlin (1886, p. 160).

8 See Zucker (1975, p. 65).

9 On the conferences, see Russell (1898). For further discussion of the managerial void in the emergence of the international gold standard, see Gallarotti (forthcoming).

10 Young (1982) calls such regimes "spontaneous."

11 For recent studies of the gold standard, see Bordo and Schwartz (1984) and Eichengreen (1985).

12 Since the value per bulk of gold was roughly 15 times greater than that of silver, gold would naturally become more important as a medium of exchange in environments where the size and frequency of transactions and incomes were growing. In this case, the metal with lower transaction costs would grow in importance vis-à-vis the metal with higher transaction costs. As Redish (1990b) notes, however, the success of a gold standard in the period depended upon an effective system of token coinage (i.e., one which minimized counterfeiting and shortages of token coin). Silver retained an important role in this function throughout the nineteenth century.

13 See US Congress, Senate (1867, p. 51) (hereafter International Monetary Conference).
14 National monetary authorities in this period were strongly metallist. Paper rated lower in the monetary hierarchy than either silver or gold. As John Sherman (1895, p. 387) noted, an irredeemable paper currency was a "national dishonor." The prevailing ideological preference ordering of the period with respect to monetary standards was: gold preferred to bimetallism preferred to silver preferred to paper.

15 Russell (1898, p. 148).

16 In this period, the term "civilized nations" was commonly used as a synonym for economically developed nations.

17 Russell $(1898$, p. 239). Other foundations for ideological prejudices such as gold's intrinsic superiority or rarity seem to have been much less compelling in this period. Although Alexander Hamilton did acknowledge some such sources of attraction in the latter eighteenth century. See Laughlin (1886, pp. $13,14)$.

18 US Congress, Senate (1879, p. 80) (hereafter International Monetary Conference).

19 Willis (1901, p. 103)

20 International Monetary Conference (1879, pp. 53, 54, 91).

21 Kindleberger $(1975$, p. 51) notes that the British example was central to the proliferation of free trade policies in Europe from 1850 to 1875 . In monetary matters, Clough and Cole (1946, p. 623) identify Great Britain as a monetary model which, through example, exported practices governing currency, note issue, and circulation.

It is interesting to note here that although both laissez-faire/free trade and gold standards compelled for similar reasons, monetary practices did not see the same reversals (i.e., away from laissez-faire) that other issue areas experienced. In this respect money can be considered the last bastion of nineteenth century liberalism. This may have had something to do with the fact that states had greater institutional obstacles (i.e., central banks) in the area of money, while in trade and social policy, for example, there were few pre-existing institutions to overcome.

22 Great Britain looked to the Dutch two centuries earlier when developing its own banking system. See Kindleberger (1984, p. 52).

23 Farmer ([1886] 1969, p. 45). See also Friedman (1990a, p. 1168, 1990b, p. 94)

24 Quoted in Slater (1886, p. 45).

25 International Monetary Conference $(1879$, pp. 241, 242)

26 International Monetary Conference $(1879$, pp. 241, 242)

27 This displacement strongly manifested itself in the developed world in the 1850 s and 1860 s. Massive gold discoveries (the average yearly world production of gold in fine ounces increased almost fourfold from the 1840s to the 1860 s, while the production of silver on yearly average increased less than twofold) altered the market bimetallic ratio so as to overvalue gold and undervalue silver at mints, thus causing the circulation of gold to swell at the expense of the circulation of silver, as it became profitable to import and coin gold, and melt down and export silver. 
The organization of German monetary unification in the Reichstag in the early 1870 s was the most pronounced example of an individual personally orchestrating a policy agenda. Bismarck, in a political quid pro quo, allowed Liberal discretion over monetary policy (by relegating the question to the Reichstag where Liberals dominated), and the Liberals deferred to the monetary expertise of Bamberger, who emerged as the financial leader of the Reichstag. So pronounced was his influence over the course of German monetary unification that he lost on only one major issue (in 1874): linking the expansion of government note issue to the retirement of silver. Interestingly, the setback occurred because it violated the stable-money imperatives of the Reichstag. See Zucker (1975, pp. 65, 74-76).

28 Stern (1977, p. 180).

29 Quoted in Hamerow (1972, p. 60).

30 Rosenburg (1962, p. 14) and Kindleberger (1975). More generally, the policies liberalizing exchange were perceived as the reason for the prosperity enjoyed in Great Britain and the United States. See Hamerow (1972, p. 346).

31 Stern (1977, p. 180).

32 Hamerow (1958, p. 254).

33 Willis (1901, p. 111) argued that a component of Germany's gold ideology was that France was a de jure bimetallist, political competition leading to a preference for a different standard.

34 Senator Thomas Benton, quoted in White $(1893$, pp. 7, 8). On the politics behind the Bill, see Friedman (1990a, p. 1162).

35 Martin (1973, p. 839).

36 Quoted in Russell (1898, p. 16). Friedman (1990a, 1990b) sees the British example as compelling for the United States.

37 Sherman (1895, p. 491)

38 Unger (1964) identifies a strong ideological attachment to silver in the rural South. Friedman (1990a, p. 1162), however, observes that similar regions could manifest differing preferences for standards across time, as the Jacksonian coalition favoring gold in the 1830s and the Bryan coalition favoring silver in the 1890s drew their support from the same regional classes.

39 Sherman (1895, pp. 468, 492); O'Leary (1960, p. 389); and Laughlin (1886, pp. $100,101)$.

40 White (1893, p. 21) and Chevalier (1859). But Kindleberger (1984, p. 115) argues that France in the nineteenth century greatly admired and strove to emulate British financial institutions.

41 Chapman (1962, p. 122) and Plessis (1985, p. 62).

42 Willis (1901, p. 57).

43 Willis (1901, pp. 16, 37)

44 Helfferich (1927, p. 131)

45 US Congress, Senate (1876, vol. II, p. 61) (hereafter US Monetary Commission).

46 Russell (1898, pp. 84, 85) and US Monetary Commission (1876, vol. II, p. 137).

47 US Monetary Commission (1876, vol. II, p. 273).
48 Kindleberger $(1984$, p. 23$)$ links the origin of gold coins in Italy (the florin and genoin) in the thirteenth century to the commercial revolution which increased the need for high-value/low-bulk money.

49 The British closed the mints to silver in 1798, argued Helfferich, because they were reluctant to allow a mint-undervalued gold to be displaced in circulation by silver (1927, pp. 121, 122)

Redish (1990b, p. 805) asks why the monetary standard of Great Britain (gold as the central monetary metal with token silver), being the most convenient in the early nineteenth century, was not copied by more nations at the time. Much of the reason, I believe, is to be found in differential rates of economic development. To the extent that monetary institutions are endogenous (i.e., conditions of economic exchange influence monetary institutions), it is only natural to expect Great Britain to be the first to opt for this more convenient monetary standard because it was the first to experience the industrial revolution. Other nations were less compelled in this period, given the nature of their transactions; their industrial revolutions came in the mid-tolatter half of the century. In fact, the French Monetary Commission of 1790 resolved that gold was the natural standard of commercial nations because it was "easy of carriage," but that France at the time had neither the scale of domestic nor international trade to warrant a gold standard. See White (1891, p. 314). Helfferich $(1927$, p. 125) noted that the German compulsion toward gold in the early nineteenth century was mitigated by low incomes and the large number of small transactions. In addition, it was easier for Great Britain to attain and maintain gold stocks since London was the center of both the global gold and capital markets.

50 Laughlin argued that when the production of gold increased enormously, it was eagerly absorbed. But when the production of silver was increased to the same extent, it was not permitted to displace gold in developed nations.

51 Evidence suggests that this bias must be qualified. Both France and Belgium tolerated a displacement favoring silver from 1832 to 1847 when the market ratio caused silver to be overvalued at their mints. In the period of 1849-54 Belgium, Switzerland, Naples, Spain, and India instituted policies limiting the use of gold in response to large gold influxes into circulation. France instituted monetary commissions in 1851 and 1857 to discuss solutions to the problems of declining silver circulation. The United States in 1853 and the Latin Union nations in the 1860 s reacted to a shrinking silver circulation by altering coinage laws. It should be noted, however, that the greatest concerns relating to the retention of silver in this period were over silver as a subsidiary coin. These practices and policies defending silver were principally stimulated by shortages in small coin. Laughlin's "bias," therefore, is truer of central money metals than of metals in general. Developed nations showed a propensity to protect gold as a central monetary metal and protect silver as a subsidiary-coin metal. See Willis (1901, pp. 18, 19); Helfferich (1927, p. 139); and Martin (1973).

52 See the most recent debate over whether the practice of bimetallism in the nineteenth century led to alternating monometallism (Greenfield and Rockoff, 
1991 and Redish, 1990a) or in fact maintained both metals in circulation (Rolnick and Weber, 1986). I find Redish and Greenfield and Rockoff's evidence more compelling.

53 Of course, even under a gold standard, nations required a stable token-coin system. See Redish (1990b).

54 On the use of the concept of "tipping" in the selection of money, see Greenfield and Rockoff (1991). My use of tipping does not suggest, as Greenfield and Rockoff's use does, that Gresham's Law might not work (when tipping occurs), but only that people would have found its workings undesirable if these workings resulted in gold shortages.

55 Of course, if the market ratio were kept close to the mint ratio, then bimetallism could maintain itself. But this assumes that people would not systematically discriminate against silver as a medium of exchange, which events in this period suggest is not the case. Furthermore, and as Friedman (1990a, 1990b) acknowledges, maintaining bimetallism would require price support schemes for silver when it was losing its value and threatening to drive gold out of circulation. In the 1870 s and 1880 s, given the severity of events in the silver market, it is dubious that any small core of nations could have stabilized the price of silver. In any case, nations were afraid to begin a price support scheme unilaterally. In fact, in discussing such support schemes at international monetary conferences, the most powerful nations (especially Great Britain) preferred to freeride by keeping their mints closed to silver while others opened theirs. The schemes failed to be instituted for typically collective-action reasons. See Russell (1898).

56 Milward and Saul (1973, p. 422) and Bouvier (1970, p. 342).

57 In Germany, the stable-money Liberals in the Reichstag perceived a greater urgency to go to gold just for this reason. They believed that a silver standard or bimetallism would be more inflationary because people would not transact in silver, thus putting pressure on the government to orchestrate greater issue of bank notes. See White (1893, pp. 14, 15).

58 Kindleberger (1984, pp. 108, 120) and Clare (1909, p. 113).

59 Keynes ([1913] 1971, p. 12) cited the customary traditions of collecting railway fares and paying wages in gold.

60 Neither the categorization of development nor the links to monetary diplomacy developed here is unproblematic. Norway appears as an exception. It did not experience an industrial revolution in the nineteenth century, but pursued monetary practices consistent with the Scandinavian trend. Holland may represent an anomaly in this logic as well. Finally, the United States developed roughly as fast as or faster than all of the other nations except for Great Britain.

61 Russell (1898) and Willis (1901). The recent literature on bimetallism has shown greater sensitivity to the effects of transaction costs on the working of Gresham's Law, but has underplayed the effects of social preferences based on convenience (i.e., whether society will accept the displacement of a convenient medium of exchange). See Friedman (1990a, 1990b) and Redish (1990a). An exception to this is Greenfield and Rockoff's (1991) use of the concept of tipping.
62 Flotow (1941).

63 Zucker (1975, p. 65).

64 This view is supported by Joseph Ropes in his testimony to the US Monetary Commission (1876, vol. II, p. 199).

65 US Monetary Commission (1876, vol. I, p. 33) and Sherman (1895).

66 Helfferich $(1927$, p. 137).

67 Willis $(1901$, p. 6). In a survey conducted by the French Monetary Commission of 1867 , results showed a disproportionate support of gold on the part of French chambers of commerce and tax collectors. See Helfferich (1927, p. 146).

68 See also Laughlin (1886, p. 152)

69 White $(1891$, p. 334).

70 Willis (1901, p. 17)

71 Willis $(1901$, p. 28, 29).

72 Nielsen (1933, p. 598)

73 From 1844 to 1864 the aggregate trade of France, Great Britain, and the United States increased threefold from $\$ 11.5$ to $\$ 32.7$ billion. See US Monetary Commission (1876, vol. I, pp. 22, 23).

74 Ford (1962, p. 94)

75 Chevalier (1859, p. 207).

76 Such initiatives came out of the International Exhibition in London in 1851 and the International Statistical Congresses in Brussels in 1853 and 1855.

77 The German Trade Congress in 1867 called for international monetary unification based on a gold franc. The Reichstag in 1868 and the Customs Parliament in 1869 called for German entrance into international union. See Helfferich (1927, pp. 151, 152).

78 Zucker (1975) and US Congress, Senate (1868, p. 2) (hereafter Report of the Committee on Finance).

79 Cecco (1974, pp. 58, 59) and Clough and Cole (1946, p. 688).

80 Laughlin (1886, p. 114). More generally, the nature of urban versus rural transactions created a natural division of preferences. Urban interests, which transacted more often and in larger amounts, preferred gold, while rural dwellers, who transacted less frequently, were less burdened by the use of silver. Almost all rural areas in the developed world before 1850 transacted principally in silver. Russell (1898, p. 15), in fact, noted that it was the "plain people" in America that complained of the disappearance of silver after changes in the coinage ratio in 1837 . Of course, neither exclusively transacted in their preferred metal, given the need for token coins in cities and larger-coin transactions in rural areas. See Redish (1990b).

81 Laughlin (1886, p. 114).

82 Even in the 1850 s, when gold depreciated vis-à-vis silver, French creditors preferred to be paid in gold. See Willis $(1901$, p. 8). Although Russell (1898, p. 85) noted that creditors in this period were not uncomfortable accepting silver as well. However, by the 1870s there was little question regarding creditors' preferences. Whatever ambivalence was created by cheap gold in the 1850 s and 1860 s, was gone by the 1870 s when silver depreciated precipitously vis-à-vis gold. 
83 See the statement of the Belgian delegate Pirmez in International Monetary Conference (1879, p. 124). It is interesting that the Bank of France maintained its preference for bimetallism even in the $1870 \mathrm{~s}$. In this instance, its own historical success in bimetallic arbitrage overcame a natural disdain for a depreciating metal (silver). But it should also be noted that it traditionally adhered to silver when its gold reserves were abundant. Once the gold drain became serious in the $1870 \mathrm{~s}$, the Bank was quick to reverse its traditional defense of bimetallism. See Willis (1901, p. 60).

84 Monetary authorities in developed nations during this century were far too wedded to metallism ever to consider a paper standard as a long-run option.

85 Laughlin (1886, p. 6).

86 Essentially, he was attempting to sustain a pre-capitalist political structure in what had become a capitalist society. See Stern (1977, pp. 177-183) and Rosenburg (1962).

87 Kindleberger (1984, p. 120)

88 Zeldin (1958, p. 2).

89 In 1852, landowners made up 19 percent of the legislature, while former civil servants and the grand bourgeoisie made up 26 percent and 24 percent respectively. See Plessis (1985, pp. 31-37).

90 Cammaerts (1921, pp. 317, 318)

91 Dandliker (1899)

92 Albrecht-Carrie (1950, p. 192) and Lovett (1982, p. 47).

93 Stromberg (1931, pp. 647-667).

94 Birch (1938, pp. 322-351)

95 Barnouw (1944, pp. 187-192).

96 The royal attachment to silver in Holland appears to have been strongly based on ideology, i.e., maintaining monetary tradition. In France, executive advocacy of bimetallism was founded on strong ties to the Bank of France.

97 Derry (1968, p. 177).

98 Milward and Saul (1973, p. 520)

99 Inflationist groups were able to coopt urban labor by convincing them that the expanded metallic base assured by bimetallism was more conducive to high wages.

100 The taxonomy shows numerous anomalies. Western bankers and businessmen commonly advocated bimetallism, and Republicans and Democrats often reversed roles on issues of resumption and the management of greenbacks. Also, Southern urban interests showed a long history of stable-money preferences. These anomalies were often founded on some conflict of interests. Among the capitalist class, it was the bankers and businessmen that had disproportionate ties to agriculture, land speculation, or rural development (i.e., investments in railroads) that were the most likely supporters of inflation. Unger (1964, pp. 158, 159), in fact, argues that such reversals among businessmen over resumption were not rare. The structure of monetary preferences dictated by this taxonomy did, however, crystallize often enough to maintain the taxonomy's usefulness as a means of categorizing the foundations of competition in monetary politics. See Sherman (1895, pp. 509-520, 540, 570, 1147); Laughlin (1886, pp. 187, 188); Friedman and Schwartz (1963, pp. 4549); Stern (1964, pp. 4, 5, 53); Blaine (1884, vol. I, p. 421; vol. II, pp. 391, 392); Upton (1884, pp. 157-162); Beard and Beard (1927, p. 297); and Clark (1920, pp. 322, 484)

101 Friedman and Schwartz (1963, pp. 54, 55, 111) cite the trends in the money stock in the 1870 s as reflective of a political balance skewed toward stable money. Later in the 1890s, they add, the political balance was still anti-inflation as evidenced by the policy rigidity of maintaining convertibility in the face of financial crisis.

102 In his testimony to the US Monetary Commission (1876, vol. II, p. 356), William Sumner argued that Europe was ready to move to gold at any time after 1850 , but that it took Germany's transition to compel the rest of the Continent.

103 Willis $(1901$, pp. 18, 19) and McCulloch $(1879$, pp. 18, 19).

104 Friedman (1990a, p. 1162) underscores the politics of the Act: a "golden club" which Jacksonian sympathizers could use against Biddle's Bank of the United States. The intention was to reduce the demand for the Bank's notes by introducing more gold into circulation.

105 Laughlin (1886).

106 See Sherman $(1895$, p. 541). Whether or not these outcomes would have been pervasive is subject to speculation. It is clear, however, that forecasts of future outcomes tended in this direction. Hence, whether the threat was real or not, it was perceived as real.

107 His concerns, like Sherman's, derived primarily from a concern with stable money.

108 Those who argue that bimetallism has the capacity automatically to reverse gold or silver shortages through a stabilizing mechanism that works via the substitution of metal between monetary and non-monetary uses (see Bordo, 1987 - such substitution will automatically bring the market ratio back to the mint ratio), assume that metals are perfectly substitutable as mediums of exchange. If they are not, people will institute coinage laws which prevent their preferred medium from being displaced (as happened in the 1870s).

109 Russell (1898, pp. 89, 90); Flotow (1941, p. 114); and Helfferich (1927, pp. 151, 152).

110 Willis (1901, p. 105).

111 Russell (1898, p. 103).

112 Willis (1901, p. 38) and Helfferich (1927, p. 146).

113 International Monetary Conference $(1879$, p. 190). By the time this act was passed, at least a majority of the metallic transactions in Switzerland were in gold.

114 Redish (chapter 3 in this volume) suggests the possibility that Napoleon III may have been using the bimetallist position as a bargaining chip to be later traded away to the community of nations in return for considering international monetary union around the franc at the Conference of 1867 . This is 
problematic, given that Napoleon would have had correctly to predict that the community of nations would accept the idea of the franc but reject international bimetallism. See Russell (1898).

115 This assured that silver would not displace gold in circulation since it was undervalued and gold overvalued at Latin Union mints. In this respect, the Union did not intend (in the short run, anyway) to deviate from gold monometallism in practice. See Willis (1901, pp. 40-46) and Redish (chapter 3 in this volume).

116 Helfferich (1927, p. 143) noted that the Conference definitively conveyed that "gold was the standard of the future." Willis (1901, p. 135) regarded it as the beginning of a global consensus on the desirability of a gold standard.

117 International Monetary Conference (1879, p. 81). John Sherman (1895, p. 412) expressed the same view.

118 Quoted in Slater (1886, p. 39). See also Russell (1898, pp. 84, 236).

119 Russell (1898, p. 103).

120 Helfferich (1927, p. 149).

121 The extraordinary rise in silver imports from 1861 to 1865 is due to the fact that Indian cotton took up the slack of declining US cotton exports caused by the American Civil War.

122 Greater use of notes, a less favorable balance of trade, and the greater use of council bills to clear payments with Great Britain were responsible for a dropoff in silver imports after 1865.

The US Monetary Commission of 1876 cited the drop in India's net imports as one of the major factors (along with policy changes in Europe and silver production) accounting for the depreciation of silver in the 1860s and 1870s. The Commission's conclusion was representative of a widespread belief of this period.

123 The price of silver on the London market changed by only $\frac{9}{16} \mathrm{ppp}$ (pence per ounce) from 1865 to 1871 (from $61 \frac{1}{16} \mathrm{ppp}$ to $60 \frac{1}{2} \mathrm{ppp}$ ) when India's net silver imports went from $\$ 93$ million (in 1865) to almost $\$ 5$ million (in 1870) Furthermore, the price of silver did not change by more than $\frac{3}{16} \mathrm{ppp}$ from 1869 to 1872 , years which saw extremely sharp swings in the level of net imports (see Table 2.1). In these cases, changes in flows did not produce large enough changes in the stock of silver to alter the price significantly. See Laughlin (1886, p. 224).

124 Council bills were bills of exchange sold by the India Council (the government of India residing in London) for the purpose of making payments to Great Britain for public expenses such as interest on debt and pensions. Since these bills represented claims on silver in India, they increasingly substituted for shipments of silver, as they would be purchased by those in Great Britain who needed to send silver to India in payment for goods. On the effects of council bills on silver flows, see Laughlin (1886, pp. 126, 127).

125 John Sherman (1895, p. 412) attributed the decline in the value of silver in the 1860 s solely to the increased production of silver.

126 The average yearly quinquennial increase in the production of world silver
The scramble for gold in the 1870s

from $1861-65$ to $1866-70$ was equal to 36 percent of the average yearly net silver imports into India in the period 1866-70.

127 The market ratio changed from $15.44: 1$ in 1865 to $15.57: 1$ in 1870 . The legal ratio in Latin Union nations was $15 \frac{1}{2}: 1$. After 1866, the market ratio never again dropped below $15 \frac{1}{2}: 1$. See Laughlin (1886, pp. 223, 224).

128 Actually, the Latin Union nations might have pre-empted Germany onto gold if it had not been for the strategic political maneuvers of the French Ministry of Finance, and the Franco-Prussian War. From 1865, Belgium, Switzerland, and Italy had been advocating a Latin Union based on gold monometallism. Even the French delegates at the founding of the Union in 1865 had requested a gold union. French society and the legislature were strongly behind gold. The perpetuation and exportation of a bimetallist standard to the Union in the midand late 1860 s resulted from the deft actions of the Ministry of Finance at keeping the matter out of the legislature and under the jurisdiction of the Ministry. In 1869, for example, Minister Magne responded to a call for assessing France's monetary standard by referring the matter to the Conseil Supérier of Agriculture, Commerce, and Industry rather than the Chambers, which was overwhelmingly predisposed to pass a gold bill. The Ministry further protected bimetallism by not making public the Conseil's decision supporting gold over silver and bimetallism (by 26 to 11) until 1872. With the advent of the Franco-Prussian War and the problem of the indemnity, any meaningful changes had to wait until after 1873 . The Ministry was successful at keeping the matter out of the Chambers until 1876, when a law was passed suspending the coinage of 5 -franc silver pieces. A Ministry more sympathetic to gold could have had France and the Latin Union (since Latin Union nations configured their monetary standards to that of France) officially on a gold standard well before Germany. See Willis (1901, pp. 105-107).

It is difficult to impute motives other than support for haute finance and the Bank of France to the French Ministry in its defense of bimetallism. Arguments that suggest France was holding out to get into a more advantageous position as leader of a gold bloc on the Continent fail to address the fact that France's intransigence threatened to drive her Latin Union satellites into a gold union with Germany, certainly an undesirable outcome for the French government and Ministry of Finance.

129 Such contagion was not an issue in the working of bimetallism before 1860 because perceptions attributed a cyclical rather than secular character to the market for metals.

130 See the testimonies of William Sumner and Joseph Ropes in US Monetary Commission (1876, vol. II, pp. 312, 355).

131 Quoted in Russell (1898, p. 105).

132 Willis (1901, p. 113); Russell (1898, p. 89); and Helfferich (1927, p. 149).

133 US Monetary Commission (1876, vol. II, p. 356). The urgency of early liquidation of silver was all the more enhanced by the desire to maximize gold stocks for the impending legal transition to a full gold standard. This necessitated exchanging silver at its maximum purchasing power, which was perceived to be 
at the beginning of a secular decline.

134 Helfferich (1927, p. 444). Helfferich (p. 149) contended that one of the principal considerations driving Germany to gold was a fear of being "isolated" in a world destined to move toward gold monometallism.

135 US Congress, House $(1878$, p. 5) (hereafter Report of the Commissioners).

136 See O.D. Ashley's letter in US Monetary Commission (1876, vol. II, p. 61).

137 Willis (1901, p. 163).

138 The Swedish rix thaler, in fact, exactly corresponded with the Hamburg rix thaler. See International Monetary Conference (1867, p. 35); Russell (1898, p. 58); and Helfferich (1927, p. 144).

139 US Monetary Commission (1876, vol. I, pt. 2, p. 170)

140 White (1893, p. 23) and Upton (1884, p. 230)

141 See Nielsen (1933, p. 598) and Holmboe's statement in US Monetary Commis sion (1876, vol. I, pt. 2, p. 518).

142 Willis $(1901$, pp. 56, 57, 143) argued that the Union was engineered by France and Napoleon III as a means of extending France's monetary hegemony on the Continent. The proximate reason of the Union's formation, of course, was a response to disturbances in subsidiary silver coin circulation owing to the fact that Swiss and Italian token coins were struck at lower finenesses. See Redish (chapter 3 in this volume).

143 This replication mirrored a very strong trade dependence. See US Monetary Commission (1876, vol. II, pt. 2, p. 144) and Willis (1901, p. 15).

144 The monetary dependence of Switzerland and Belgium was particularly acute owing to a historically large circulation of French coin within their borders. By the end of the $1850 \mathrm{~s}$, for example, most of the metallic transactions in Switzerland were in French gold. In 1860, 87 percent of the coins in circulation in Belgium were French. With respect to trade, the Latin Union satellites were especially dependent given their large trade sectors. Belgium, for example, was consuming only about $\frac{1}{14}$ th of its total yearly production in this period.

145 International Monetary Conference (1867, p. 45).

146 Helfferich (1927, p. 146).

147 Stolper (1940, p. 32) called the German policy initiative one of "extraordinary significance" in moving the developed world toward a monetary transformation. McCulloch $(1879$, p. 14) saw it as the pivotal, crucial event urging the world to a gold standard. William Sumner's testimony portrayed the German policy change in similar terms. See US Monetary Commission (1876, vol. II, p. 356). See also Friedman (1990b, p. 90).

148 To the extent that this perception drove Germany onto gold, it is not unreasonable to attribute some element of self-fulfilling prophecy onto the scramble for gold itself. It is clear, however, that irrespective of this perception, structural forces and secular conditions in the market for metals were pushing Germany and the Continent to gold. This perception merely increased the urgency to adopt gold. More is said on the role of self-fulfilling prophecy below.

149 The French indemnity was the main cause of the silver inflow given that it was liquidated in such a way as to shift French assets to Germany, thus making
Germany's international creditor position greater. In the second quarter of 1871 , for example, Great Britain exported 2 million pounds' worth of silver to Germany. Also of note was the decline in Indian net silver imports in 1870: they had gone from over $\$ 36$ million in 1869 to less than $\$ 5$ million in 1870 (see Table 2.1).

Much has been said about the importance of gold transfers from the indemnity in making possible Germany's transition to a gold standard. But in actuality very little gold was transferred. Only 15 percent ( 742 million out of 5 billion francs) of the indemnity was actually liquidated in money, and only 5 percent (273 million francs) was liquidated in gold. It was principally liquidated in stocks, credits, and bills of exchange. Germany, in fact, experienced no net increase in her gold stocks until she began liquidating her excess silver on the world market in 1873. See US Monetary Commission (1876, vol. I, pt. 2, p. 79); Willis (1901, p. 110); and Russell (1898, p. 107)

150 The net imports of silver into Sweden increased from 3,129 kilograms in 1870 to almost 28,000 in 1872 . Sweden coined more than twice as much silver in 1871 than it had in 1870 (4,361 to 9,975 kilograms). Norway imported more than three times as much specie in 1871 (mostly silver) than it had in 1870 . See US Monetary Commission (1876, vol. II, pt. 2, pp. 516-528).

151 Helfferich (1927, p. 175)

152 White (1893, p. 23).

153 Estimates of Hector Hay and Ernest Seyd show an increase from $\$ 51$ million to $\$ 61$ million. See Laughlin (1886, p. 218).

154 Willis (1901, p. 136).

155 By the Economist's estimates global gold production declined from $\$ 108$ million in 1871 to $\$ 87$ million in 1872 . See Laughlin $(1886$, p. 218$)$.

156 Because of relatively smaller endowments of precious metals in monetary use, the transition in Germany's Northern satellites caused less concern. The impact of their conversion was mainly psychological, as the realization of an expected trend that would engulf the developed world. See Helfferich (1927, p. 175).

157 Upton (1884, p. 208) directly attributed the demonetization of silver in Holland and Latin Union nations to the fear of this mass of German silver displacing their gold circulations.

158 International Monetary Conference (1879, p. 57). In actuality, the reality fell somewhat short of the fears. German authorities were careful in liquidating their supply of silver out of fear of depressing the world price of the metal. It was not until 1876 that any significant amount of silver was actually liquidated. Up until 1876 most of the territorial coins called in were used for coining Imperial silver coins. Of the years 1873 to 1876 , only in 1874 was more silver liquidated than was assigned to German mints for coinage. Of the estimated 856.7 million marks of silver that Germany needed to dispose of (i.e., that silver stock in monetary use above the subsidiary coin needs of the German population) in 1873 , only 204.9 million had been liquidated by 1876 . This figure was only 14 percent of the world's total silver production in that four-year period. 
See Helfferich (1927, p. 170) and US Monetary Commission (1876, vol. II, pt. 2 pp. 77, 78).

159 Laughlin (1886, p. 224).

160 Laughlin (1886, p. 225).

161 Willis (1901, p. 115).

162 Willis (1901, pp. 89, 90, 116, 301-313).

163 Willis (1901, pp. 114-126).

164 Willis (1901, pp. 127, 128).

165 Willis $(1901$, pp. 137, 138, 143) called the agreement a compromise between bimetallists and gold advocates. Defenders of bimetallism argued that the conditions in the market for metals were cyclical, and it was fully expected that the values of gold and silver would once more gravitate to levels that would allow silver and gold to circulate concurrently as central monetary metals, and therefore definitive long-run commitments to a gold standard were premature.

166 Interestingly, the governments of Belgium, Switzerland, and Italy all used this agreement to strengthen themselves fiscally. They purchased the requisite silver bullion on the open market, coined the entire amount immediately (thus crowding out private citizens), and deposited the sums with their treasuries. See Willis (1901, pp. 150, 151).

167 From May to November 1874, 32 million gulden in silver had been coined.

168 Helfferich (1927, p. 176).

169 In France, net gold imports slightly increased, while net silver imports declined enormously. Substantially more gold was now being coined in both France and Belgium.

170 Willis (1901, pp. 158-160).

171 Up until this year, the Ministry of Finance, erstwhile defender of bimetallism in France, was able to keep it out of the Chambers where gold had resounding support.

172 Also at the basis of France's unilateral move was a pronounced fear of being pre-empted onto gold by the Swiss, who had been requesting a gold Union for some time, and the Belgians whom recent elections had placed under the leadership of Frère-Orban and his pro-gold Liberals. See Willis (1901, pp. 162-165).

173 Except, of course, for Italy which was exempted for one year.

174 Sherman $(1895$, pp. 541, 615, 617, 618) and Blaine (1884, vol. II, p. 605). See also the various testimonies and letters to the US Monetary Commission (1876, vol. I). There is some debate on the magnitude of the influence of these external concerns behind the demonetization of the silver dollar in the Act of 1873 . O'Leary (1960) argues that the principal author of the bill, H.R. Linderman, was compelled by critical developments in Europe and the world market for metals. Friedman and Schwartz (1963, p. 115) are somewhat skeptical as to Linderman's principal motivation. It is clear, however, that as early as 1872 , Linderman did acknowledge the potential dangers of both the increased supply of silver in the world and the change of standards in Germany. And, in fact, Friedman (1990a, pp. 1165-1167) more recently appears to converge closer to O'Leary's position.
175 Blane (1884, vol. II, p. 606).

176 Linderman suggested that any such unilateral initiative by one nation would lead other nations to think, "Here is a good chance ... to get rid of our silver." See US Monetary Commission (1876, vol. II, p. 198). Pirmez, the Belgian delegate at the International Monetary Conference of 1878, argued that any viable multilateral return to bimetallism must include all important silver nations, otherwise free-riders would use the new union to liquidate their excess silver. See Russell (1898, p. 215).

177 This represented a fairly common response to the US Monetary Commission's question: What would be the consequences of remonetizing silver in the United States? See the testimonies of Fitch, Ropes, and Sumner in US Monetary Commission (1876, vol. II, pp. 35, 313, 345).

The severity of the perceived consequences (among monetary authorities) of incurring the "sucker's payoff" (i.e., opening their mints to silver while other nations did not) leads us to question Friedman's (1990a, p. 1174, 1990b, p. 91) contention that a unilateral resumption of bimetallism by the United States in the mid-1870s could have stabilized the bimetallic market ratio. The events in Latin Union nations and the failure of the Dutch resumption in 1874 made nations extremely reluctant to initiate or support any unilateral actions in this direction. And given the propensity of free-riding behavior among core nations, it is likely that a unilateral US initiative would have invited much of the surplus silver from the Continent. It is doubtful that the United States could have withstood this rapid and large flood of silver.

178 In describing this policy, France's Léon Say underscored the threat which was felt from the large pool of excess silver in Germany yet to be liquidated. See International Monetary Conference (1879, pp. 55, 56).

179 Quoted in Helfferich (1927, p. 181).

180 Russell (1898, p. 227) identified an element of self-fulfilling prophecy in what he called the "vicious circle" of the 1870s: "states were afraid of employing silver on account of the depreciation, and the depreciation continued because the states refused to employ it."

181 Structural and proximate factors leading to the scramble were inextricably connected. A large component of the nervousness in the 1860 s and 1870 s were fears of unstable money, fears which were nurtured by shifting structures of political power. (The US Monetary Commission, 1876, vol. I, p. 4, underscored the importance of stable-money interests in bringing about the demonetization of silver in Europe.) The growth in trade and internationalization of finance forged stronger links which bound the monetary chain gang; as did the perception of gold as a political and economic status symbol. And the thought of losing one's gold circulation caused grave concern. All this enhanced the nervousness over the anticipation of changes in foreign monetary practices.

182 Keynes ([1913] 1971, p. 53) noted how the forced circulation of gold in India in 1900-01 failed because the sovereign (owing to its high value) was not suitable for such a poor country.

183 In Portugal's case it appears that both financial and trade dependence on Great Britain overcame some structural impediments in determining their monetary 
standard. I am indebted to Jaime Reis for these facts pertaining to the Portuguese case.

184 Schumpeter $(1954$, p. 770$)$.

185 The ruling oligarchs were trying to arrest the appreciation of their exchange rate. See Ford (1962, pp. 167-169).

186 Interestingly, these factors, too, tended to covary with economic development

187 Portugal shows some elements of a crucial case.

188 Whatever incongruity was created by cheap gold in the 1850 s was quickly eliminated by its relative appreciation in the 1860 s.

189 The reference here is specifically to the literature on the political business cycle, which has identified a pro-inflation bias in the politics of representative democracies. See, for example, Nordhaus (1975).

190 Insofar as redundance of monetary practices at the domestic level had international manifestations, the gold standard was an example of an additive regime: it was the sum of identical parts. Other such additive regimes are conceivable. For example, a group of nations each instituting unilateral free trade would form a free trade bloc. Non-additive regimes would dictate that domestic policies differ: macroeconomic policy-coordination regimes, for example, dictate that nations take different positions on the Phillips curve.

\section{References}

Albrecht-Carrié, René, 1950. Italy From Napoleon to Mussolini, New York: Columbia University Press.

Barnouw, A.J., 1944. The Making of Modern Holland: A Short History, New York: Norton.

Beard, Charles and Mary Beard, 1927. The Rise of American Civilization, vol. II New York: Macmillan.

Birch, J.H.S., 1938. Denmark in History, London: John Murray.

Blaine, James G., 1884. Twenty Years of Congress From Lincoln to Garfield, 2 vols., Norwich: Henry Bill.

Bordo, Michael, 1987. "Bimetallism," in J. Eatwell, M. Milgate and P. Newman (eds.), The New Palgrave, London: Macmillan.

Bordo, Michael and Anna Schwartz (eds.), 1984. A Retrospective on the Classical Gold Standard: 1821-1931, Chicago: University of Chicago Press.

Bouvier, Jean, 1970. "The banking mechanism in France in the late 19th century," in Rondo Cameron (ed.), Essays in French Economic History, Homewood: Irwin: 341-369.

Cammaerts, Emile, 1921. A History of Belgium, New York: Appleton

Campbell, Colin and William Dougan (eds.), 1986. Alternative Monetary Systems, Baltimore: Johns Hopkins University Press.

Cecco, Marcello de, 1974. Money and Empire: The International Gold Standard, 1890-1914, Totowa: Rowman \& Littlefield.

Chapman, Guy, 1962. The Third Republic of France: The First Phase 1871-1894, New York: St. Martin's Press.
Chevalier, Michel, 1859. On the Probable Fall in the Value of Gold, trans. Richard Cobden, New York: Appleton.

Clare, George, 1909. A Money-Market Primer, and Key to the Exchanges, London: Effingham Wilson.

Clark, Champ, 1920. My Quarter Century in Politics, vol. I, New York: Harper \& Brothers.

Clough, Shepard and Charles Cole, 1946. Economic History of Europe, Boston: Heath.

Dandliker, Karl, 1899. A Short History of Switzerland, trans. E. Salisbury, London: Swan Sonnenschein.

Derry, T.K., 1968. A Short History of Norway, Westport: Greenwood.

Dorn, James and Anna Schwartz (eds.), 1987. The Search for Stable Money: Essays in Monetary Reform, Chicago: University of Chicago Press.

Economist, October 27, 1866.

Eichengreen, Barry (ed.), 1985. The Gold Standard in Theory and History, New York: Methuen.

Farmer, E.J. [1886] 1969. Conspiracy Against Silver or a Plea for Bimetallism in the United States, New York: Greenwood.

Flotow, Ernst, 1941. "The Congress of German economists, 1858-1885: a study of German unification," Ph.D. dissertation, American University.

Ford, A.G., 1962. The Gold Standard 1880-1918: Britain and Argentina, Oxford: Clarendon Press.

Friedman, Milton, 1990a. "The crime of 1873," Journal of Political Economy, 93 (December): 1159-1194.

1990b. "Bimetallism revisited," Journal of Economic Perspectives, 4 (Fall): 85-104.

Friedman, Milton and Anna J. Schwartz, 1963. A Monetary History of the United States, Princeton: Princeton University Press.

Gallarotti, Giulio, forthcoming. "Centralized versus decentralized international monetary systems: the lessons of the classical gold standard," in James Dorn (ed.), Alternatives to Government Fiat Money, Dordrecht: Kluwer.

Gourevitch, Peter, 1978. "The second image reversed: the international sources of domestic politics," International Organization, 32 (Autumn): 881-911.

Greenfield, R. and H. Rockoff, 1991. "Gresham's law regained," Rutgers University (ms.).

Hamerow, Theodore, 1958. Restoration, Revolution, Reaction: Economics and Politics in Germany 1815-1871, Princeton: Princeton University Press.

1972. The Social Foundations of German Unification 1858-1871, Princeton: Princeton University Press.

Helfferich, Karl, 1927. Money, 2 vols, trans. Louis Infield, New York: Adelphi.

Jervis, Robert, 1976. Perception and Misperception in International Politics, Princeton: Princeton University Press.

Keohane, Robert, 1984. After Hegemony: Cooperation and Discord in the World Political Economy, Princeton: Princeton University Press.

Keynes, John Maynard, [1913] 1971. "Indian currency and finance," in The Collected Writings of John Maynard Keynes, vol. I, New York: St. Martin's Press for the Royal Economic Society. 
Kindleberger, C., 1975. "The rise of free trade in Western Europe, 1820-1875," Journal of Economic History, 35 (March): 20-55.

1984. A Financial History of Western Europe, London: George Allen \& Unwin.

Krasner, Stephen, 1982. "Structural causes and regime consequences: regimes as intervening variables," International Organization, 36 (Spring): 185-205.

Laughlin, J. Laurence, 1886. The History of Bimetallism in the United States, New York: Appleton.

Lovett, Clara, 1982. The Democratic Movement in Italy, Cambridge, MA: Harvard University Press.

Martin, David, 1973. "1853: the end of bimetallism in the United States," Journal of Economic History, 33 (December): 825-844.

McCulloch, Hugh, 1879. Bimetallism, New York: G.P. Putnam's Sons.

Milward, Alan and S.B. Saul, 1973. The Economic Development of Continental Europe 1780-1870, Totowa: Rowman \& Littlefield.

Nielsen, Axel, 1933. "Monetary unions," Encyclopedia of the Social Sciences, 10 (June): 595-601.

Nordhaus, William, 1975. "The political business cycle," Review of Economic Studies, 42 (April): 169-90.

O'Leary, Paul, 1960. "The scene of the crime of 1873 revisted: a note," Journal of Political Economy, 68 (August): 388-392.

Plessis, Alain, 1985. The Rise and Fall of the Second Empire, 1852-1871, trans. Jonathan Mandelbaum, Cambridge: Cambridge University Press.

Redish, Angela, 1990a. "Bimetallism in nineteenth century France: a razor's edge," University of British Columbia (ms.).

1990b. "The evolution of the gold standard in England," Journal of Economic History, 50(4): 789-805.

Rolnick, A. and W. Weber, 1986. “Gresham's law or Gresham's fallacy?," Journal of Political Economy, 94 (February): 185-199.

Rosenberg, Arthur, 1962. The Birth of the German Republic 1871-1918, New York: Russell \& Russell.

Russell, Henry, 1898. International Monetary Conferences: Their Purposes, Character and Results, New York: Harper \& Brothers.

Schumpeter, Joseph, 1954. History of Economic Analysis, New York: Oxford University Press.

Sherman, John, 1895. John Sherman's Recollections of Forty Years in the House, Senate and Cabinet, 2 vols., Chicago: Werner.

Slater, M.H., 1886. Money. A Brief Treatise on Bimetallism in Plain Words, Washington: National Bimetallic Coinage Association.

Stern, Clarence, 1964. Golden Republicanism: The Crusade for Hard Money, Ann Arbor: Edwards Brothers.

Stern, Fritz, 1977. Gold and Iron: Bismarck, Bleichröder, and the Building of the German Empire, New York: Knopf.

Stolper, Gustav, 1940. German Economy 1870-1940, New York: Reynal \& Hitchcock.

Stromberg, Andrew, 1931. A History of Sweden, New York: Macmillan.
Unger, Irwin, 1964. The Greenback Era: A Social and Political History of American Finance, 1865-1879, Princeton: Princeton University Press.

Upton, J.K., 1884. Money in Politics, Boston: D. Lothrop.

US Congress, House, 1878. Report of the Commissioners on Behalf of the United States to Attend the International Monetary Conference, 45th Congress, 3rd Session, October 17.

US Congress, Senate, 1867. International Monetary Conference of 1867, 40th Congress, 2nd Session, December 19.

1868. Report of the Committee on Finance on Bills, Reports, and Memorials Relating to International Coinage, 40th Congress, 2nd Session, June 9.

1876. US Monetary Commission, vols. I and II, 44th Congress, 2nd Session, August 15.

1879. International Monetary Conference of 1878,45 th Congress, 3rd Session, February 6.

White, Horace, 1891. "Bimetallism in France," Political Science Quarterly, 6 (June): 311-337.

1893. The Gold Standard, New York: Evening Post Publishing Co.

Willis, H.P., 1901. A History of the Latin Monetary Union: A Study of International Monetary Action, Chicago: University of Chicago Press.

Wolfers, Arnold, 1962. Discord and Collaboration: Essays on International Politics, Baltimore: Johns Hopkins University Press.

Young, Oran, 1982. "Regime dynamics: the rise and fall of international regimes," International Organization, 36 (Spring): 277-297.

Zeldin, Theodore, 1958. The Political System of Napoleon III, London: Macmillan.

Zucker, Stanley, 1975. Ludwig Bamberger: German Liberal Politician and Social Critic, Pittsburgh: University of Pittsburgh Press. 